\title{
Irregular status, territorial confinement, and blocked transnationalism: legal constraints on circulation and remittances of Senegalese migrants in France, Italy, and Spain
}

Erik R. Vickstrom ${ }^{1 *}$ and Cris Beauchemin ${ }^{2}$

\section{* Correspondence:}

erikvickstrom@gmail.com

${ }^{1}$ IZA - Institute for the Study of Labor, Washington, USA

Full list of author information is available at the end of the article

\begin{abstract}
This paper explores the link between legal status and transnational engagement through the lenses of territorial confinement and blocked transnationalism. We hypothesize that irregular legal status results both in direct territorial confinement-an inability to visit the homeland - and in indirect caging of remitting, an important non-mobile transnational activity. This caging is hypothesized to result from an attenuation of social ties associated with reduced physical co-presence with kin and other important individuals in the homeland. Using longitudinal data on Senegalese migrants in France, Italy, and Spain from the MAFE Project, we find that Senegalese migrants who lack of secure legal status are effectively confined to the destination territory, preventing them from making short visits to the homeland. The direct and indirect relationships between irregular status and remittances, though, vary by destination country: the hypothesized relationships are not evident for migrants in Spain, indicating the role played by other facets of the context of reception, such as policy tolerance and the characteristics of the co-ethnic community.
\end{abstract}

Keywords: Legal status, Irregularity, Transnational activities, Remittances, Circulation

\section{Introduction}

Migrants have long maintained ongoing social, economic, and political connections with their homelands, but these transnational activities have garnered increased attention from scholars and policymakers since the 1990s. Academic research has shown that modern travel and communications technologies have created new kinds and quantities of transnational engagement, findings which have challenged the notions of the state control of borders and of unidirectional immigrant settlement and assimilation. International development agencies and destination-country governments, especially in Europe, have begun to recognize the potential of transnationally engaged migrants to be active participants in the development of their home communities. Such "co-development" strategies seek to leverage migrant cross-border activities, such as remittances, investment, and participation in hometown associations, as part of

(c) 2016 The Author(s). Open Access This article is distributed under the terms of the Creative Commons Attribution 4.0 International License (http://creativecommons.org/licenses/by/4.0/), which permits unrestricted use, distribution, and reproduction in any medium, provided you give appropriate credit to the original author(s) and the source, provide a link to the Creative Commons license, and indicate if changes were made. 
overall development strategies. At the same time, migration policies in Western European countries have tended to constrain more and more heavily the possibilities for migrants to stay and work legally, and thus produce a growing population of irregular migrants (Triandafyllidou, 2010).

In this paper, we show that these two policy orientations (co-development and migration restrictions) are paradoxical, if not contradictory, by studying the constraint that irregular legal status may place on cross-border engagement. Our quantitative approach distinguishes between mobile transnational activities, i.e. visits to the homeland, and non-mobile activities, such as remitting. Many studies recognize occasional physical visits to the homeland to be an important component of the transnational social field, both as an important link between destination and origin in its own right and as a crucial way to maintain the social links that sustain non-mobile activities such as remitting. Yet most research does not consider the direct constraint on physical mobility faced by migrants without secure legal status or the effect that such reduction in mobility might have for non-mobile, long-distance activities.

This paper explores the link between legal status and transnational engagement through the lenses of territorial confinement and blocked transnationalism. We hypothesize that irregular legal status results both in direct territorial confinement-an inability to visit the homeland-and in indirect caging of remitting, an important nonmobile transnational activity. This caging is hypothesized to result from the attenuation of social ties and social obligations associated with reduced physical co-presence with kin and other important individuals in the homeland from which migrants often draw their sense of status.

The Migrations between Africa and Europe (MAFE) survey of Senegalese migrants in France, Italy, and Spain provides the empirical data on which these hypotheses are tested. Senegalese migrants are renowned in the qualitative literature for practicing "transnational livelihoods" predicated on circulation between the destination and the homeland and the accumulation of material wealth and social status in Senegal in preparation for an eventual return. At the same time, Senegalese migrants often lack secure legal status: those without "papers" are often "stuck" in the destination country and may thus face challenges in constructing a transnational existence. Thus the development potential of this group of migrants-courted by the French and Spanish governments and coveted by the Senegalese state-may be short circuited by lack of secure legal status. Interestingly, the MAFE survey offers the possibility to test the validity of our hypotheses in multiple contexts of reception, i.e. France, Italy, and Spain. The immigration-policy contexts in these three countries have varied over time, creating multiple configurations of legal statuses among Senegalese migrants.

This paper is organized as follows. The next section reviews the literature on transnational activities and argues that state immigration-control policies create irregular legal statuses that have both direct and indirect effects on both mobile and non-mobile transnational activities. We then review the data and methods, highlighting the advantages of MAFE's longitudinal data on both transnational activities and legal statuses and the models we use to estimate direct and indirect effects. The results of these models show that Senegalese migrants are territorially confined by irregular legal status, limiting their ability to visit their homeland. The effects on remitting, however, are more complicated and not only depend directly and indirectly on legal status but also 
vary by destination. The final sections discuss these results, with an emphasis on why the effects of legal status vary by national context, and conclude with implications of the findings for policies of immigration control and co-development.

\section{Literature review}

This section reviews the literature on the role of the state in migrants' transnational activities, arguing that immigration-control policies may constrain cross-border action. We examine how irregular legal status could limit transnational activities by considering the direct effects of irregularity on both mobile transnational activities, such as visits to the homeland, and non-mobile transnational activities, such as remitting. We then argue that there may be a relationship between visits to the homeland and nonmobile transnational activities, based on the maintenance of social ties; this relationship may then transmit an indirect effect of irregular legal status on remitting through legal constraints on circulation. Finally, we present our hypotheses and the empirical case of Senegalese migrants in Europe.

\section{The role of the state in migrants' transnational activities}

Following Portes, Guarnizo, and Landolt's (1999) call to delimit and measure the phenomenon of transnationalism empirically, the 2000s have seen a flowering of studies of a myriad of kinds of transnational activities among a wide variety of groups (for a review, see Levitt \& Jaworsky, 2007). Many studies have shown that individual characteristics such as age, education, occupation, and length of residence in the host community are associated with a variety of transnational activities (Guarnizo, 2003; Guarnizo, Portes, \& Haller, 2003; Itzigsohn \& Saucedo, 2002). What has been underemphasized in this literature, however, is how state immigration-control apparatuses and the legal statuses they produce may also structure transnational activities. Given the widespread acknowledgement of the preponderant role that legal status plays in the incorporation of migrants in the destination society (Massey, 2007; Portes \& Rumbaut, 2006), it is surprising that scholars have not paid more attention to the impact that legal status may have on the transnational activities that have been shown to accompany such integration.

This underemphasis may be due, in part, to a tension in the transnational-studies literature regarding the conceptualization of the role of the state. Much of the early literature on migrant transnational activities focused on the challenge that these activities posed to national borders. Transnational activities explicitly take place across borders and seemingly despite state attempts at control, indicating a weakness or even an inability of the state to control flows of people, money, ideas, and values (Glick Schiller, Basch, \& Blanc, 1995).

In this view, the state and its territorial border-and the national membership that this frontier implies-have difficulty containing the globe-spanning networks that "transmigrants" construct via their incessant physical, social, and economic connections to the homeland. These connections, it is argued, are possible mainly because of technological advances in travel and communications that compress time and space: jumbo jets make formerly insurmountable distances between destination and origin easily traveled, and mobile phones and the internet allow migrants to be in daily touch with their families in the homeland (Diminescu, 2008; Vertovec, 2003). While 
subsequent research has questioned the argument that cross-border engagement is a novel form of social action (Foner, 1997) and has nuanced the depiction of the fluidity of transnational life (Levitt \& Jaworsky, 2007), new technologies have undoubtedly made transnational activities easier and cheaper, and have thus had an impact on the quantity and kinds of cross-border engagement (Diminescu, 2008; Portes, Guarnizo, \& Haller, 2002).

Other research has argued for the importance of the state in the study of transnational activities. Waldinger $(2008,2010,2015)$ argues that international migrants have and will always participate in these kind of cross-border activities; what is missing from the account, he argues, is analysis of the ability of the state and its borders to bound both identificational and territorial belonging. First, the identificational demands of modern nation-states encourage legally resident migrants with an initially transnational orientation to abandon it in favor of identification with the destination polity, leading to "societal divergence" (Waldinger, 2015). Second, states and their efforts to control borders can act to "cage" migrants, both through processes of settlement and territorial confinement. State efforts to control movement across borders effectively confine irregular migrants to the territory of the destination country; this constraint on physical mobility entails the progressive attenuation of the social ties that nourish cross-border engagement (Waldinger, 2008, 2015). Waldinger (2008) describes this process as "double capture" in which the destination state constrains the cross-border engagement of both documented and undocumented migrants.

Critiques of Waldinger's approach have questioned the centrality and influence he accords to the state, as well as his depiction of the withering of social ties underlying transnationalism. Schiller (2015) agrees that the state is an important element in power relations structuring transnationalism, but argues that a multiscalar global perspective situates the locus of power in global capitalism and not the state. Levitt (2015) argues that the social ties underlying transnationalism are more durable than Waldinger's depiction and questions the power of the state to undermine them. Itzigsohn (2015) contends that Waldinger is too uncritical in his depiction of societal divergence, and argues that the process of incorporation may need to new forms of exclusion that reignite the connection between immigrants or their descendants and their homelands. Critics also contend that Waldinger's focus on Latin American migrants in the US may bias his findings by not considering other contexts of receptions and types of migrants (Levitt, 2015).

These critiques point out important limitations in Waldinger's (2015) efforts to explain the constraints on transnationalism, but they also recognize the contribution of an approach that seeks to understand the variation in transnational practices. As Levitt notes, a crucial challenge for the study of transnationalism is to "...explain why ties and engagements persist, attenuate, or fade away" and to research "...how, why and where transnational practices remain strong over time and for whom - what patterns emerge, what classes of people stand out, and what kinds of governance structures encourage or dampen transnational livelihoods" (pp. 2283-2284). Waldinger's contribution is to further this effort by examining patterns of transnational practices and offering explanations for the "how, why and where" that Levitt calls for. His explanation is rooted in the ability of the state to police its borders and ensure social closure in ways that impinge upon the ability of migrants to maintain social ties with those at home and engage in transnational activities. 


\section{Territorial confinement of migrants with irregular legal status}

How does the legal reality of the state, its borders, and the concomitant legal statuses-which the research reviewed above contends exert a powerful influence on transnational activities-actually constrain the cross-border actions of migrants? The answer to that question depends, in part, on the action under consideration. Some transnational activities may be more sensitive to legal constraints than others, especially those that depend in some way on migrants having a secure legal status in the destination society. The most relevant example is travel between destination and origin. Dunn (2010, p. 5) notes that crossing national borders "is not so free and easy": while international travel is certainly much cheaper and quicker in the contemporary world than before, destination states remain capable of restricting movements across their borders. Despite some early exaggerations of mobility, research on transnationalism has underscored this continued power of borders (Dunn, 2010). As Waldinger (2008) points out, migrants do not come and go as they please, but only engage in physical cross-border mobility to the extent that states allow it, and scholars have begun calling for approaches to transnationalism that grapple with the political and legal constraints on mobility (Boccagni, 2012b; Mountz, Wright, Miyares, \& Bailey, 2002).

Legal status is clearly the key factor in allowing migrants to travel freely between destination and their home communities: those migrants who lack secure legal status are less likely to engage in this kind of physical circulation because they are not guaranteed re-entry and do not want to risk the cost and potential danger of an unauthorized entry (Massey, Durand, \& Malone, 2002). Empirical research demonstrates the relationship between legal status and circulation. Kaag (2008) finds that Senegalese migrants in Italy without "papers" describe themselves as being "stuck" because they do not want to expose themselves to the cost and risk of an additional irregular passage. Waldinger (2008) finds that homeland visits are the most common form of cross-border activity among his sample of Colombians, Cubans, Dominicans, and Salvadorans, and he also finds that secure legal status strongly predicts the probability of travel home. Immigration policies are thus a crucial conditioning factor for this form of cross-border engagement: migrants who lack secure legal status experience a "territorial confinement" (Waldinger, 2008) that constrains their movement across national borders. We thus hypothesize a direct negative effect of irregular legal status on migrants' propensity to return home for short visits because of the legal barrier to mobility inherent in irregular status.

\section{Structural exclusion and blocked transnationalism}

While the constraint that irregular legal status places on physical circulation between destination and origin is unambiguous, the legal constraint of this status on other transnational activities is less clear. Why would, for instance, irregular legal status constrain remittances, a transnational activity that does not necessarily involve the migrant's physical crossing of a border? The literature suggests a mechanism: migrants with an irregular status are in a situation of structural exclusion, which, in turn, blocks their ability to perform cross-border activities (Bloch, 2008; Mazzucato, 2008; Van Meeteren, 2012). Lack of regular legal status can, for example, prevent migrants from participating in the formal labor market, relegating them to informal, precarious, and low-paid jobs; this insecurity could make them less likely to have the means to remit. 
Lack of regular legal status could also constrain participation in various financial institutions: not having a bank account or not being able to access credit could reduce migrants' abilities to send remittances to and invest in assets at home, for example. We thus hypothesize a mechanism of blocked transnationalism that would manifest itself by a direct negative effect of irregular legal statuses on remitting because of the structural exclusion it engenders.

\section{Social ties to home and non-mobile transnational activities}

The territorial confinement and structural exclusion hypotheses both posit a negative effect of irregular legal statuses on migrants' cross-border activities: irregular status simultaneously constrains migrants' abilities to cross the destination state's borders (a mobile transnational activity) and to participate in formal institutions that allow them to engage in other forms of cross-border engagement, especially through remittances (a non-mobile transnational activity). Beyond these independent effects of legal status on either mobile or non-mobile transnational activities, the literature suggests a potential relationship between physical mobility and transnational activities: occasional physical border-crossing may nurture social relationships-affective ties, but also social obligations-that fuel cross-border engagement (Guarnizo et al., 2003; Itzigsohn \& Saucedo, 2002). If lack of secure legal status constrains visits to the homeland, this constraint could be transmitted to long-distance, non-mobile activities by the weakening of social ties.

What is it about visits home that might encourage other kinds of transnational engagement? Some studies of transnationalism have asserted that advances in communications technologies have helped migrants transcend the physical distance to their friends and family in the homeland and create "a perception of intimate connectedness" with them (Wilding, 2006, p. 138). Virtual co-presence, in this view, substitutes effectively for, and may even surpass, physical co-presence in nourishing the social links that motivate and sustain regular cross-border social engagement (Diminescu, 2008). While scholars of mobility have recognized the potential for communications technologies to compress space and time in novel ways, there is still some doubt about the ability of virtual communication to replace physical face-to-face interactions (Boccagni, 2012a). Mobility research has found, for example, that interactions involving physical copresence are necessary for developing extended relations of trust (Urry, 2002). Indeed, even communications at a distance, while allowing some maintenance of social ties, may actually increase the need to reinvigorate these relationships via occasional physical co-presence (Boccagni, 2012a; Urry, 2002). Physical visits to the homeland may thus allow migrants to build and renew the trust and emotional identification that underlie long-distance social ties. Furthermore, research has shown that transnational activities are embedded in a web of family-based obligations (Menjivar, DaVanzo, Greenwell, \& Valdez, 1998) and moral economies (Carling, 2008). There is evidence that visits to family and physical co-presence with them "have the potential to consolidate relationships of reciprocity" (Baldassar, 2008, p. 263) and thus reinscribe migrants in the family-based moral economy in ways that may encourage non-mobile transnational activities upon return to the destination.

Other studies of transnationalism suggest that physical circulation between destination and origin is important in facilitating other transnational activities in instrumental, rather 
than affective, ways. Visits allow migrants to gather first-hand information on the wellbeing of their families, the suitability of business opportunities and partners, and the overall socioeconomic conditions of their communities (Carling, 2008) and could thus inform decisions to send money, invest in assets, and participate in collective development efforts. Riccio (2001) argues that visits home are crucial for the transnational livelihoods of Senegalese migrants in Italy, which involve frequent trips back to Senegal to facilitate investments and other business dealings. Research often assumes the importance of crossborder travel for other transnational activities but leaves it unanalyzed. Portes and associates (Portes et al., 2002; Portes \& Zhou, 2012) assert that transnational entrepreneurship is at least partially dependent on the ability to be physically present both "here" and "there," but the actual practice of short visits to the homeland is not included as a predictor variable in models. Waldinger (2008) analyzes the regularity and recency of home-country travel, but does not directly examine its effect on other cross-border activities.

Occasional physical presence in the homeland is thus of clear importance for the maintenance of social ties, the renewal of family obligations in the transnational moral economy, and the instrumental gathering of information, which are themselves the crucial social infrastructure of transnational flows. We thus hypothesize a positive direct effect of short returns (visits) on non-mobile transnational activities, such as remitting.

\section{Indirect caging of non-mobile transnational activities}

A relationship between short visits to the origin community and other transnational activities opens the door to the possibility of an indirect effect of irregular legal statuses on non-mobile transnational activities. Waldinger $(2008,2015)$ argues that states effectively "cage" migrants with irregular legal status by constraining their movement across borders. This caging not only limits migrants' physical movement but also, by limiting physical co-presence with important people "back home," constrains their social ties to the homeland. Short returns home thus act as a mediator of irregular legal statuses. If migrants with irregular legal status experience territorial confinement that constrains their ability to circulate, and if short visits to the homeland allow migrants to maintain social ties and gather information, and if these ties and information encourage migrants to participate in other forms of cross-border action, then migrants with irregular legal status should participate less in those forms of cross-border action that depend in some way on at least occasional physical presence in the homeland.

While the literature is suggestive of this indirect effect of irregular legal status on non-mobile transnational activities, few studies have simultaneously examined either the direct relationship between short returns and non-mobile transnational activities or the indirect relationship between irregular legal status and non-mobile transnational activities transmitted via inhibited cross-border mobility. Waldinger (2008, p. 24) notes that "better settled migrants with secure legal status are more likely to engage in activities requiring physical presence in the homeland," but he does not examine the impact that migrants' legal status has on both physical presence in the homeland and the activities that require such presence. Carling (2008) points out that migrants who do not visit home cannot directly observe whether their families use remittances as intended. We thus hypothesize that irregular legal status will indirectly constrain non-mobile transnational activities. Migrants who do not have the ability to circulate between 
destination and origin because of their irregular legal status are effectively prevented from engaging in transnational livelihoods that depend on this circulation.

\section{Framework of hypotheses}

Figure 1 summarizes the hypothesized relationships between irregular legal status and Senegalese migrants' cross-border engagement. The territorial confinement hypothesis (H1) posits a direct legal constraint of irregular status on migrants' short returns to Senegal. The structural exclusion (H2) hypothesis postulates a direct legal constraint of irregular status on migrants' abilities to participate in formal institutions that may promote non-mobile cross-border engagement; irregular status is thus a proxy for unmeasured blockages of participation in such institutions. The social ties (H3) hypothesis suggests a link between short returns and non-mobile transnational engagement via the maintenance of social links and obligations and the ability to gather first-hand information through occasional physical presence in the homeland. Finally, the caging hypothesis ( $\mathrm{H} 4)$ posits that the territorial confinement of migrants with irregular statuses (H1) constrains social ties with the homeland (H3) in a way that dampens non-mobile cross-border engagement. Irregular legal status thus constrains cross-border action in a multitude of direct and indirect ways that depend, in part, on the crossing of physical and institutional borders.

\section{The empirical case}

To test this set of hypotheses we study the case of Senegalese migration in Europe in three different countries, namely France, Italy and Spain. This case is interesting for at least two reasons: first, Senegalese migrants are known for the intensity of their transnational connections and, second, Senegalese migrants' three main destination countries in Europe offer quite varied contexts of reception.

Senegalese migrants in Europe and across the globe have been noted for their regular and sustained participation in the lives of the kin and communities they left behind in their homeland. Studies of Senegalese migrants have argued that they live their lives across borders in multiple places simultaneously and that the dominant mode of organization of their migration experience is transnational (Kane, 2011) with an overriding goal of creating economic, social, and spiritual lives in Senegal to which they hope to return (Riccio, 2008). Indeed, Senegalese are quite active in a number of transnational spheres, with remittances playing a large role. Official monetary remittances to

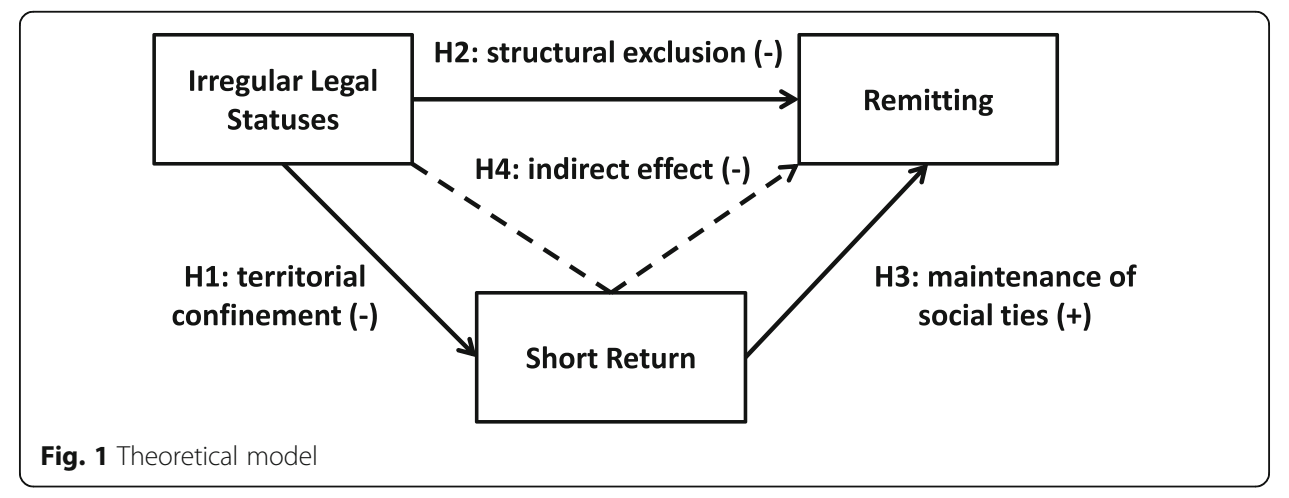


Senegal almost tripled between 2002 and 2010, rising from $\$ 305$ million to $\$ 1.16$ billion, or about $10 \%$ of GDP (Cisse, 2011). In terms of the absolute value of remittance flows, Senegal ranks fourth in sub-Saharan Africa, behind only demographic giants Nigeria, Kenya, and Sudan, while it ranks fourth in remittances as a percentage of GDP behind the much smaller countries of Lesotho, Togo, Cape Verde, and Guinea-Bissau (Cisse, 2011). In addition, official remittances are thought to make up only $54 \%$ of total remittances (Sarr, 2009).

Short visits to Senegal by migrants residing abroad are an integral part of what Kaag (2008) calls a "circular transnational livelihood," facilitating trade and other economic transactions (Riccio, 2008). Quantitative work on Senegalese migration has shown that Senegalese are more likely than other groups (namely Ghanaians or Congolese) to make visits to their home country: half of Senegalese migrants visit Senegal within five years of departure, while only a third of Ghanaians and $10 \%$ of Congolese do so (Schoumaker et al., 2013). Their families also tend to be transnational: family reunification is lower among Senegalese migrants than among other African migrants in Europe, with spouses commonly remaining in Senegal (Beauchemin et al., 2015; Mazzucato, Schans, Caarls, \& Beauchemin, 2015). Senegalese migrants thus participate in a wide variety of transnational activities, lending credence to the assertion that they organize their migration strategies along transnational lines.

Despite this transnational way of life, qualitative studies have also demonstrated that Senegalese migrants' cross-border activities are constrained by their lack of secure legal status (Kaag, 2008; Kane, 2011). Riccio $(2001,2008)$ highlights the important role that acquisition of the permesso di soggiorno plays for Senegalese migrants in Italy: without it, they are not able to practice the circular transnational livelihoods that purportedly mark the Senegalese migration experience. The legal constraint is all the more important given the often precarious administrative situations in which Senegalese migrants in Europe find themselves (Vickstrom, 2014). Senegalese have long been suspected of participating in "clandestine" or irregular migration strategies in Europe. Senegalese migrants were often seen as "false tourists" in France during the late 1960s (Diop, 1993; Spire, 2005) and were publicly visible in the sans papiers movement in the 1990s (Timera, 1997). In Italy and Spain, they remain among the nationalities with the highest rates of irregularity (UNODC, 2013). Research has also demonstrated that variation in these three countries' immigration policies has created different configurations of irregularity among Senegalese migrants (Vickstrom, 2014).

Given both the deep transnational involvement and the varied contexts of reception and configurations of legal statuses of Senegalese migrants in Europe, we must ask how the direct and indirect relationships between irregular legal status and transnational activities described above might vary across these destinations. We offer two hypotheses that suggest that these effects depend not only on destination, but also type of transnational activity. First, we expect the legal constraint of irregular legal status on visits home to be similar across destinations. Given the increasing restrictiveness of immigration-control policies in the three countries over time, especially in regards to border crossings, we expect all three contexts are thus similarly confining for those migrants lacking legal status. Second, we expect the direct and indirect effects of irregular status on remitting to vary with the context of reception. As there is no firm legal constraint of irregular status on this activity, the direct and indirect effects, or lack thereof, 
will reflect factors such as hostility or tolerance of immigration policies, the risk of deportation, and the presence and composition of co-ethnic social networks.

\section{Data and methods}

\section{Longitudinal data from the MAFE Project}

The analyses performed in this paper rely on data from the Migration between Africa and Europe (MAFE-Senegal) Project (Beauchemin, 2015), ${ }^{1}$ which conducted retrospective life-history interviews with samples of Senegalese migrants in France, Italy, and Spain. The project randomly selected Senegalese migrants from municipal registers (Padrón) in Spain, and used quota methods with a variety of recruitment methods in other destination countries (Beauchemin, 2015). The multi-sited character of the MAFE data (both at origin and destination with comparative data) allows inclusion in the analyses of individuals who have returned to Senegal after a stay in Europe and thus avoids potential biases in the retrospective measurement of transnational activities. Furthermore, the inclusion of three different countries (France, Italy and Spain) permits study of the extent to which transnational practices vary or not according to the context of reception. Longitudinal and time-varying analyses, which are important as both legal status and transnational participation are likely to vary from year to year over a migrant's stay at destination, are possible thanks to the retrospective nature of the data.

The life-history interview elicited a wide range of information about individual migrants for each year between birth and 2008. The questionnaire included modules on legal status and transnational activities for those years that the migrant spent outside of Senegal. The analytic sample includes all person-years during which an individual was a migrant in France, Italy, or Spain, including person-years contributed by return migrants in Senegal who spent time in one or more of the three European countries. Migrants interviewed in any of the European countries may also contribute person-years to the analysis of other countries if they previously spent time in those countries (i.e., migrants can have more than one trip). The total analytic sample comprises 658 individuals contributing 8,188 person years. The French subsample contained 264 individuals and 3,677 person-years, the Italian subsample contained 200 individuals contributing 2,413 person-years, and the Spanish subsample comprised 198 individuals and 2,098 person years.

\section{Outcome and predictor variables}

The MAFE project collected individual life histories in a comparative fashion in all countries. It provides detailed retrospective information on some transnational activities, including short returns to Senegal and remittances-the outcomes of our analyses-and also a wide range of variables that influence cross-border connections, including the migrants' legal status, the main variable of interest in our analyses.

The outcome variables (visiting and remitting) are dichotomous. They are coded " 1 " each time the transnational activity is observed, "0" otherwise. For visits, the variable indicates when migrants returned to Senegal for less than one year without the intention of staying there. For remittances, the interviewer asked if the individual regularly sent money to someone who lived in a different country, and, if so, during which periods and to which country. The corresponding variable is coded "1" for each year in which a migrant reported sending money to someone living in Senegal. 
The main predictor variable of interest in our analysis is legal status, which was selfreported by individuals for each year lived outside of Senegal. In this paper, we use two distinct variables. One refers to the time of entry in Europe and indicates whether the individual entered with or without a visa. The other is a composite categorical timevarying variable indicating the work and residential legal status in each year during the migrant's residence in Europe. Four categories are distinguished that combine the two types of permits (work and residence): RP_WP ("fully regular status"), NRP_WP ("mixed status, no residence permit"), RP_NWP ("mixed status, no work permit"), NRP_NWP ("fully irregular status"). Distinguishing between work and residence permits was a way to allow for the collection of legal status histories in all sorts of contexts (all countries where migrants lived, whatever the period). Mixed statuse$\mathrm{s}$-having one kind of authorization but not the other-are theoretically possible. In France, for instance, asylum seekers are not allowed to work, ${ }^{2}$ and the same restriction has applied to reunified spouses in Spain (González-Ferrer, 2011). It is worth mentioning, however, that migrants experience a mixed status quite infrequently-less than $4 \%$ of person-years-and most likely as a result of somewhat rare dysfunctions in the receiving states' immigration-control bureaucracies, or simply as the result of poor recall on the part of migrants. A focus will thus be given to clear-cut statuses when interpreting the results.

Other explanatory variables that are commonly expected to influence the probability to engage in transnational activities are included in the models. Contextual variables include the destination country and the period of arrival in Europe. Other variables are related to individuals' characteristics and to their social environment. They give insights on socio-demographic characteristics (years of education, sex, and age), economic conditions (employment status and self-reported well-being), conditions of migration (number of years since arrival, ${ }^{3}$ age at migration, number of previous migrations to Europe), social networks at destination, and social context of exit (place of origin, ethnicity, religion, familial connections with individuals in Senegal, father's schooling as a measure of the socioeconomic status of the sending family).

\section{Estimating direct effects}

To take into account both the multi-variate determination of cross-border connections and the ordering of events, we estimated two series of models: (a) a visit to Senegal and (b) sending remittances. In both cases, logit models were run first for all migrants, whatever their destination (pooled models), and second by destination. A personspecific random intercept was introduced in the models to take into account repeated observations at the individual level, to capture unobserved heterogeneity in the propensity to engage in the outcome, and to minimize endogeneity bias from omitted variables (Rabe-Hesketh \& Skrondal, 2008). The model can be written as

$$
\operatorname{logit}\left\{\operatorname{Pr}\left(y_{i t}=1 \mid \mathbf{x}_{i t}, \zeta_{i}\right)\right\}=\beta_{1}+\mathbf{x}_{i}^{\prime} \beta_{2}+\mathbf{x}_{i t}^{\prime} \beta_{3}+\zeta_{i}
$$

where $y_{i t}$ is the dichotomous outcome indicator of participation in a given transnational activity (either visiting or remitting) for person $i$ during year $t, \beta_{1}$ is a constant, $\mathbf{x}_{i}^{\prime}$ is a vector of time-constant explanatory variables, $\mathbf{x}_{i t}^{\prime}$ is a vector of time-varying explanatory variables (including the legal status, see details above), ${ }^{4} \beta_{2}$ and $\beta_{3}$ are regression coefficients, and $\zeta_{i}$ is the person-specific random intercept, assumed to be independent 
across respondents $i$. Estimates were produced using Stata version 12's xtlogit command, which employs adaptive Gauss-Hermite quadrature to approximate the likelihood function (Rabe-Hesketh \& Skrondal, 2008). Sensitivity tests indicated forty-eight quadrature points were appropriate for fitting the models accurately.

For these multivariate models, results are displayed as average marginal effects (AMEs). AMEs are useful for the interpretation of non-linear models and capture the expected change in the probability of the outcome associated with a one-unit or discrete change in a predictor variable (see Cameron \& Trivedi, 2010 for more information on average marginal effects). Mood (2010) argues that AMEs are appropriate for non-linear model comparisons, which is helpful when comparing the effect of a given variable across different models. For these random-effects models, AMEs are calculated assuming that the group-specific intercept is set at the mean of the distribution of the random intercepts (i.e., zero). It is also useful to note that the results are subjectspecific probabilities, and not population-average probabilities: they refer to the yearly individual probability of engaging in each transnational activity.

\section{Estimating indirect effects in a non-linear framework}

The caging hypothesis posits an indirect effect of legal statuses on non-mobile transnational activities via the mediating variable of short returns. Estimation of this indirect effect is straightforward in a linear regression model: the difference in the coefficients for the legal-status variables in models with (the "reduced model") and without (the "full model") the mediator variable can be considered the indirect effect of that variable. In a non-linear framework, however, the underlying latent outcome variable has a scale that is unknown and depends on the predictors included in the model, and thus calculating indirect effects in nonlinear models using techniques developed for linear regression conflates rescaling with mediation (Kohler, Karlson, \& Holm, 2011; Mood, 2010). Kohler, Karlson, and Holm propose a method (hereafter, "KHB method") for effect decomposition in a non-linear framework (Karlson \& Holm, 2011). They propose extracting the information that is not contained in the predictor variable of interest from the mediator by calculating the residuals of a regression of the mediator on the predictor variable of interest and using the residuals of this regression, which have the same standard deviation as the mediator variable itself and thus induce the same scale for the coefficients, in the reduced model. The KHB method will allow the calculation of the indirect effects of legal statuses on non-mobile transnational activities as transmitted by the mediator variable of short visits to the homeland.

\section{Results}

\section{Descriptive results}

Descriptive results provide support for the first two hypotheses. Migrants with irregular statuses return home less frequently, indicating that territorial confinement accompanies these irregular statuses. Migrants with irregular statuses remit less, indicating that their lack of secure legal status directly blocks them from cross-border action (Table 1). Indeed, across destinations, migrants with both a residence and a work permit (RP_WP) report short returns to Senegal in $39 \%$ to $43 \%$ of person-years, against $3 \%$ to $8 \%$ for those without any permit (NRP_NWP). Migrants with only residence 
Table 1 Descriptive statistics for MAFE-Senegal sample, by destination and legal status

\begin{tabular}{|c|c|c|c|c|c|c|c|c|c|c|c|c|c|c|c|c|c|c|c|c|c|c|c|c|}
\hline \multirow[t]{3}{*}{ Variable } & \multicolumn{8}{|l|}{ France } & \multicolumn{8}{|l|}{ Spain } & \multicolumn{8}{|l|}{ Italy } \\
\hline & \multicolumn{2}{|c|}{$\begin{array}{l}\text { Fully } \\
\text { irregular }\end{array}$} & \multicolumn{2}{|c|}{$\begin{array}{l}\text { Mixed } \\
\text { (no RP) }\end{array}$} & \multicolumn{2}{|c|}{$\begin{array}{l}\text { Mixed } \\
\text { (no WP) }\end{array}$} & \multicolumn{2}{|l|}{$\begin{array}{l}\text { Fully } \\
\text { regular }\end{array}$} & \multicolumn{2}{|c|}{$\begin{array}{l}\text { Fully } \\
\text { irregular }\end{array}$} & \multicolumn{2}{|c|}{$\begin{array}{l}\text { Mixed } \\
\text { (no RP) }\end{array}$} & \multicolumn{2}{|c|}{$\begin{array}{l}\text { Mixed } \\
\text { (no WP) }\end{array}$} & \multicolumn{2}{|c|}{$\begin{array}{l}\text { Fully } \\
\text { regular }\end{array}$} & \multicolumn{2}{|c|}{$\begin{array}{l}\text { Fully } \\
\text { irregular }\end{array}$} & \multicolumn{2}{|c|}{$\begin{array}{l}\text { Mixed } \\
\text { (no RP) }\end{array}$} & \multicolumn{2}{|c|}{$\begin{array}{l}\text { Mixed } \\
\text { (no WP) }\end{array}$} & \multicolumn{2}{|l|}{$\begin{array}{l}\text { Fully } \\
\text { regular }\end{array}$} \\
\hline & mean & $\mathrm{sd}$ & mean & sd & mean & $\mathrm{sd}$ & mean & $\mathrm{sd}$ & mean & $\mathrm{sd}$ & mean & $\mathrm{sd}$ & mean & $\mathrm{sd}$ & mean & $\mathrm{sd}$ & mean & $\mathrm{sd}$ & mean & $\mathrm{sd}$ & mean & $\mathrm{sd}$ & mean & sd \\
\hline Short returns & 0.03 & 0.17 & 0.17 & 0.37 & 0.17 & 0.38 & 0.39 & 0.49 & 0.03 & 0.17 & 0.36 & 0.49 & 0.22 & 0.42 & 0.31 & 0.46 & 0.08 & 0.27 & 0.28 & 0.45 & 0.25 & 0.43 & 0.43 & 0.50 \\
\hline Remitting to Senegal & 0.51 & 0.50 & 0.72 & 0.45 & 0.51 & 0.50 & 0.76 & 0.43 & 0.68 & 0.47 & 0.68 & 0.48 & 0.57 & 0.50 & 0.78 & 0.41 & 0.50 & 0.50 & 0.84 & 0.37 & 0.70 & 0.46 & 0.81 & 0.40 \\
\hline Entry status: no visa & 0.37 & 0.48 & 0.00 & 0.00 & 0.35 & 0.48 & 0.35 & 0.48 & 0.59 & 0.49 & 0.20 & 0.41 & 0.39 & 0.49 & 0.34 & 0.47 & 0.54 & 0.50 & 0.23 & 0.43 & 0.79 & 0.41 & 0.60 & 0.49 \\
\hline Years i & 4.88 & 3.98 & 10.50 & 8.02 & 9.65 & 9.16 & 12.50 & 9.30 & 2.53 & 1.72 & 3.90 & 2.26 & 6.51 & 5.47 & 7.60 & 5.28 & 3.80 & 3.76 & 6.56 & 5.04 & 7.84 & 5.68 & 9.13 & 5.56 \\
\hline ric & 7 & 0.50 & 0.15 & 0.35 & 0.37 & 0.48 & 0.34 & 0.47 & 3 & 0.25 & 1 & 0.00 & 0.80 & 0.40 & 0.79 & 0.41 & 0.82 & 0.39 & 0.83 & 0.38 & 0.72 & 0.45 & 0.66 & 0.47 \\
\hline Age at start of current migra & 26.10 & 9.14 & 26.20 & 6.25 & 28.40 & 7.28 & 26.70 & 7.12 & 28.40 & 7.24 & 27.50 & 5.69 & 27.80 & 6.40 & 28.10 & 6.89 & 27.70 & 5.64 & 27.00 & 4.65 & 26.50 & 5.18 & 26.30 & 5.74 \\
\hline Sex: Male & 0.52 & 0.50 & 0.72 & 0.45 & 0.56 & 0.50 & 0.60 & 0.49 & 0.87 & 0.33 & 0.75 & 0.44 & 0.46 & 0.50 & 0.82 & 0.39 & 0.86 & 0.35 & 0.92 & 0.27 & 0.83 & 0.38 & 0.94 & 0.24 \\
\hline Years of education & 9.56 & 6.56 & 6.71 & 7.18 & 9.27 & 7.98 & 9.81 & 6.72 & 5.43 & 4.94 & 2.37 & 4.01 & 5.12 & 5.78 & 7.24 & 5.19 & 9.05 & 4.23 & 10.40 & 3.76 & 9.01 & 5.08 & 10.50 & 4.45 \\
\hline Ethn & 0.35 & 0.48 & 0.42 & 0.50 & 0.39 & 0.49 & 0.26 & 0.44 & 0.67 & 0.47 & 0.04 & 0.21 & 0.47 & 0.50 & 0.49 & 0.50 & 0.79 & 0.41 & 0.75 & 0.44 & 0.74 & 0.44 & 0.85 & 0.36 \\
\hline Religion: Mouride & 0.41 & 0.49 & 0.39 & 0.49 & 0.16 & 0.37 & 0.15 & 0.36 & 0.35 & 0.48 & 0.23 & 0.43 & 0.48 & 0.50 & 0.36 & 0.48 & 0.75 & 0.43 & 0.61 & 0.49 & 0.61 & 0.49 & 0.66 & 0.47 \\
\hline Unemployed & 0.02 & 0.13 & 0.01 & 0.12 & 0.01 & 0.08 & 0.03 & 0.17 & 0.06 & 0.24 & 0.08 & 0.28 & 0.02 & 0.14 & 0.03 & 0.18 & 0.10 & 0.29 & 0.03 & 0.16 & 0.03 & 0.17 & 0.01 & 0.11 \\
\hline Employed & 0.64 & 0.48 & 0.90 & 0.31 & 0.69 & 0.46 & 0.77 & 0.42 & 0.88 & 0.32 & 0.79 & 0.42 & 0.52 & 0.50 & 0.94 & 0.24 & 0.89 & 0.32 & 0.97 & 0.16 & 0.83 & 0.38 & 0.97 & 0.16 \\
\hline Inactive & 0.34 & 0.48 & 0.09 & 0.29 & 0.30 & 0.46 & 0.20 & 0.40 & 0.06 & 0.23 & 0.13 & 0.34 & 0.46 & 0.50 & 0.03 & 0.17 & 0.02 & 0.13 & 0.00 & 0.00 & 0.14 & 0.35 & 0.01 & 0.12 \\
\hline $\mathrm{O}$ & 0.09 & 0 & 0.31 & 0.47 & 0.12 & 0.32 & 0.03 & 0.18 & 0. & 0.49 & 0.13 & 0.35 & 0. & 0.45 & 0.1 & 0.37 & 0.46 & 0.50 & 0.08 & 0.28 & 0.21 & 0.41 & 0.15 & 0.36 \\
\hline Self-reported economic status: good & 0.22 & 0.42 & 0.03 & 0.16 & 0.03 & 0.17 & 0.05 & 0.22 & 0.02 & 0.13 & 0.00 & 0.00 & 0.02 & 0.15 & 0.03 & 0.16 & 0.04 & 0.19 & 0.10 & 0.30 & 0.11 & 0.32 & 0.15 & 0.35 \\
\hline Number of contacts at destination & 2.09 & 2.21 & 1.05 & 1.57 & 3.46 & 2.68 & 4.44 & 2.85 & 1.87 & 1.75 & 1.45 & 1.54 & 3.00 & 2.08 & 2.35 & 1.96 & 2.08 & 1.89 & 3.17 & 2.32 & 2.29 & 2.22 & 2.24 & 2.04 \\
\hline Number of trips & 1.74 & 0.88 & 1.32 & 0.92 & 1.71 & 1.07 & 1.43 & 1.00 & 1.47 & 0.78 & 1.22 & 0.54 & 1.34 & 0.61 & 1.45 & 0.80 & 1.37 & 0.66 & 1.26 & 0.47 & 1.32 & 0.66 & 1.45 & 0.96 \\
\hline Does not speak la & 0.16 & 0.37 & 0.00 & 0.00 & 0.14 & 0.35 & 0.05 & 0.22 & 0.67 & 0.47 & 0.77 & 0.43 & 0.68 & 0.47 & 0.59 & 0.49 & 0.60 & 0.49 & 0.53 & 0.50 & 0.73 & 0.44 & 0.53 & 0.50 \\
\hline Kids in Senegal & 0.42 & 0.49 & 0.41 & 0.49 & 0.33 & 0.47 & 0.19 & 0.39 & 0.33 & 0.47 & 0.17 & 0.39 & 0.39 & 0.49 & 0.35 & 0.48 & 0.41 & 0.49 & 0.42 & 0.50 & 0.44 & 0.50 & 0.55 & 0.50 \\
\hline Spouse in Senegal & 0.26 & 0.44 & 0.45 & 0.50 & 0.23 & 0.42 & 0.19 & 0.39 & 0.47 & 0.50 & 0.05 & 0.22 & 0.19 & 0.40 & 0.44 & 0.50 & 0.54 & 0.50 & 0.48 & 0.50 & 0.54 & 0.50 & 0.63 & 0.48 \\
\hline Geographic origin: from Dakar & 0.20 & 0.40 & 0.13 & 0.34 & 0.26 & 0.44 & 0.21 & 0.41 & 0.30 & 0.46 & 0.14 & 0.35 & 0.20 & 0.40 & 0.33 & 0.47 & 0.51 & 0.50 & 0.45 & 0.50 & 0.34 & 0.47 & 0.45 & 0.50 \\
\hline
\end{tabular}


Table 1 Descriptive statistics for MAFE-Senegal sample, by destination and legal status (Continued)

\begin{tabular}{|c|c|c|c|c|c|c|c|c|c|c|c|c|c|c|c|c|c|c|c|c|c|c|c|c|}
\hline Father's ed.: less than secondary school & 0.64 & 0.48 & 0.74 & 0.44 & 0.65 & 0.48 & 0.62 & 0.49 & 0.78 & 0.42 & 0.88 & 0.34 & 0.77 & 0.42 & 0.82 & 0.38 & 0.80 & 0.40 & 0.75 & 0.44 & 0.67 & 0.47 & 0.72 & 0.45 \\
\hline Trip paid by family & 0.38 & 0.49 & 0.28 & 0.45 & 0.52 & 0.50 & 0.48 & 0.50 & 0.27 & 0.44 & 0.13 & 0.34 & 0.50 & 0.50 & 0.27 & 0.44 & 0.25 & 0.43 & 0.23 & 0.42 & 0.42 & 0.49 & 0.31 & 0.46 \\
\hline Plan to stay: definitive & 0.42 & 0.49 & 0.04 & 0.20 & 0.21 & 0.41 & 0.35 & 0.48 & 0.62 & 0.49 & 0.81 & 0.40 & 0.74 & 0.44 & 0.58 & 0.49 & 0.65 & 0.48 & 0.52 & 0.50 & 0.58 & 0.49 & 0.65 & 0.48 \\
\hline Trip motivation: work/better life & 0.46 & 0.50 & 0.73 & 0.45 & 0.41 & 0.49 & 0.42 & 0.49 & 0.73 & 0.44 & 0.79 & 0.42 & 0.18 & 0.38 & 0.68 & 0.47 & 0.80 & 0.40 & 0.79 & 0.41 & 0.48 & 0.50 & 0.91 & 0.28 \\
\hline At least one parent alive in Senegal & 0.91 & 0.28 & 0.88 & 0.33 & 0.93 & 0.26 & 0.75 & 0.44 & 0.89 & 0.31 & 0.95 & 0.23 & 0.86 & 0.34 & 0.81 & 0.40 & 0.74 & 0.44 & 0.93 & 0.25 & 0.81 & 0.40 & 0.81 & 0.39 \\
\hline Legal status & mean & & & & sd & & & & mean & & & & sd & & & & mean & & & & sd & & & \\
\hline Fully irregular & 0.13 & & & & 0.34 & & & & 0.26 & & & & 0.44 & & & & 0.21 & & & & 0.4 & & & \\
\hline Mixed (no RP) & 0.031 & & & & 0.17 & & & & 0.027 & & & & 0.16 & & & & 0.063 & & & & 0.24 & & & \\
\hline Mixed (no WP) & 0.1 & & & & 0.3 & & & & 0.055 & & & & 0.23 & & & & 0.12 & & & & 0.33 & & & \\
\hline Fully regular & 0.74 & & & & 0.44 & & & & 0.65 & & & & 0.48 & & & & 0.61 & & & & 0.49 & & & \\
\hline N (person-years) & 3677 & & & & & & & & 2098 & & & & & & & & 2413 & & & & & & & \\
\hline N (trips) & 768 & & & & & & & & & & & & & & & & & & & & & & & \\
\hline
\end{tabular}

Source: MAFE-Senegal. Notes: sampling probability weights applied 
authorization (RP_NWP) are less likely than migrants with either fully regular status or work-only authorization to make visits to the homeland. This indicates that a residence permit in and of itself, which should grant the legal ability to circulate, is not sufficient for successful circulation.

Overall, irregular legal status seems to constrain remitting less than short returns: the proportion of Senegalese migrants who remit is never under $50 \%$, whatever the destinations and legal-status categories (Table 1). Still, migrants with fully regular legal status are more likely to remit than migrants with fully irregular legal status. In addition, in most cases, migrants with fully regular status are also more likely to participate in this activity than migrants with mixed statuses. This general pattern holds across destinations.

The descriptive evidence supports the hypothesis that those migrants who make short returns home have a higher propensity to engage in non-mobile transnational activities and of an indirect effect of territorial confinement on remitting via the inhibition of short returns. Figure 2 shows the variation in transnational activities conditional on both short returns and legal status. Variation in non-mobile transnational activities by cross-border mobility is evident: migrants who circulate are more likely to remit. In addition, this figure shows that legal status can operate through short returns to constrain non-mobile transnational activities: migrants who lack secure legal status and, as a result, do not visit the homeland engage in remitting less frequently.

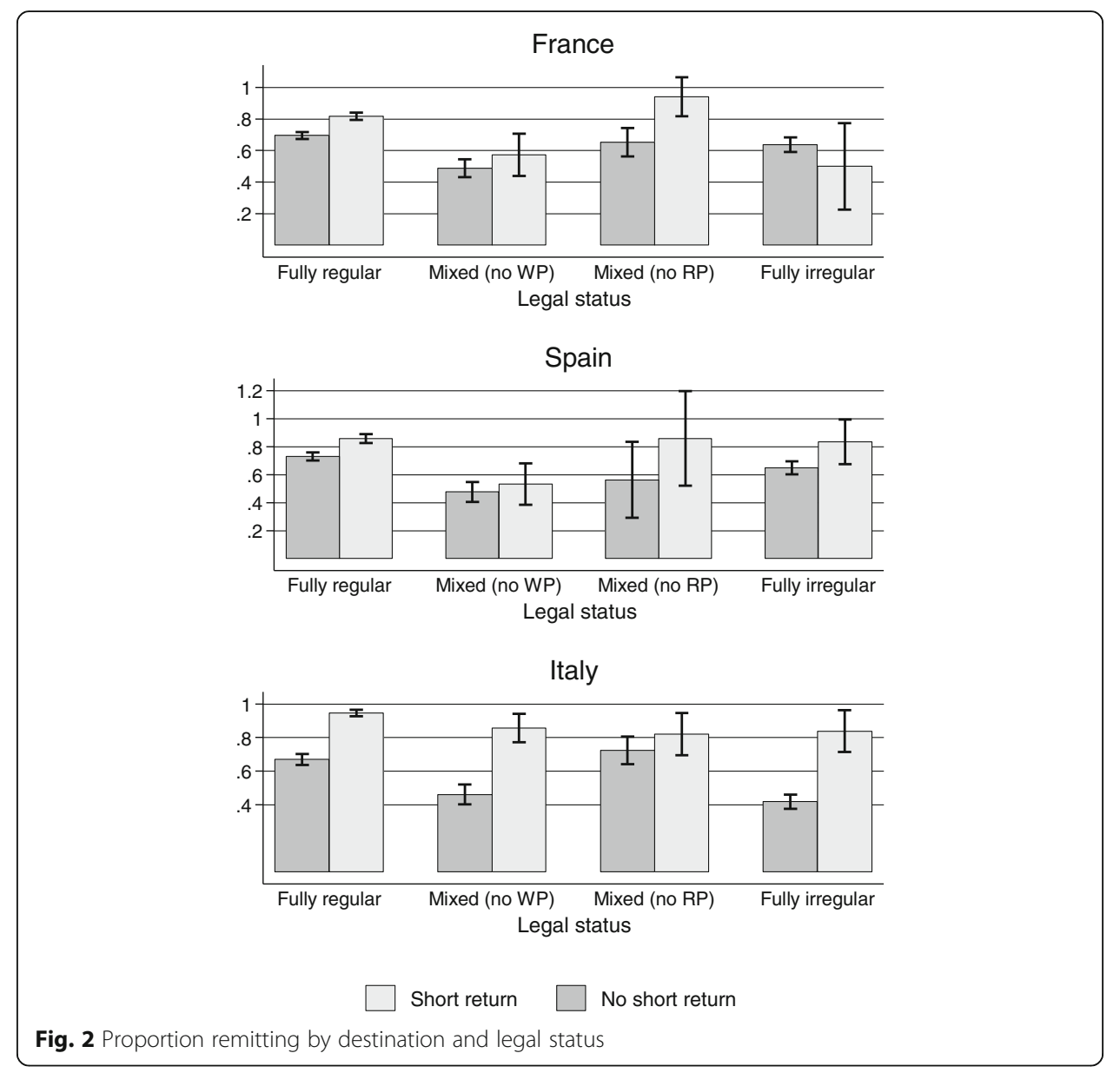




\section{Multivariate results}

\section{Hypothesis 1: territorial confinement}

Multivariate analyses indicate that the association between legal status and visiting the homeland is robust. Model I of Table 2 shows the results of the random-intercept logistic regression of yearly reports of short returns for the pooled cross-national sample. Compared to migrants with fully regular (RP_WP) status, those migrants with fully irregular or mixed statuses are statistically significantly less likely to circulate. Senegalese migrants with fully irregular (NRP_NWP) status are 22 percentage points less likely to report a visit to Senegal in any given year than migrants with fully regular (RP_WP) status. This translates into a subject-specific predicted probability of circulation for migrants with fully irregular status of $3 \%$, while those migrants with both residence and work authorization have a subject-specific predicted probability of about $25 \%$. Having fully regular status is thus associated with a seven-fold increase in the probability of making a visit home compared to having fully irregular status. Senegalese migrants who lack any kind of legal authorization have little chance of visiting the homeland because they are largely confined to the territory of the countries in which they reside. Furthermore, Models II through IV of Table 2 show that the negative effect of fully irregular status is, ceteris paribus, very consistent across the three destinations. Despite different immigration-policy contexts, then, a complete lack of legal authorization firmly constrains migrants' ability to travel home.

Table 2 also indicates that migrants with semi-irregular or mixed statuses are also less likely than migrants with fully regular status to circulate between destination and origin. Lacking only a residence permit (NRP_WP) is associated with a 14-percentage-point gap in the probability of visiting the homeland compared to migrants with fully regular status, while lacking only a work permit (RP_NWP) is associated with an 8-point gap. Countryspecific models (II through IV) show, however, that these effects are mostly concentrated among migrants in France: mixed statuses have less effect on short returns of Senegalese migrants living in Spain and Italy. On the other hand, conditions of entry have a more powerful impact in these countries, where having entered without a visa is negatively associated with short returns (models III and IV). Migrants who were irregular upon entry-a status more common in Italy and Spain than in France (see Table 1) - are likely wary of the costs of another potentially undocumented border crossing.

These multivariate results thus support the hypothesis of territorial confinement: Senegalese migrants who lack one or both forms of authorization are significantly less likely to engage in short returns to Senegal, and this effect is constant across destinations. The legal reality that creates these irregular statuses thus functions as an important constraint on this physical, mobile form of cross-border action across disparate immigration-policy regimes.

\section{Hypothesis 2: structural exclusion and blocked transnationalism}

Blocked transnationalism/structural exclusion was evident in the descriptive results: Senegalese migrants with fully regular (RP_WP) status were the most likely to engage in the non-mobile transnational activity of remitting, while migrants with fully or semiirregular statuses were less likely to participate in this activity (Table 1). This blockage as a result of lack of secure legal status is also evident in the multivariate results of Table 3. Model I of Table 3 shows the results of the random-intercept logistic 
Table 2 Multivariate results for random-intercept regression models of short returns

\begin{tabular}{|c|c|c|c|c|c|c|c|c|}
\hline \multirow[t]{2}{*}{ Predictor } & \multicolumn{2}{|l|}{ I. Pooled } & \multicolumn{2}{|l|}{ II. France } & \multicolumn{2}{|l|}{ III. Spain } & \multicolumn{2}{|l|}{ IV. Italy } \\
\hline & AME & se & AME & se & AME & se & AME & se \\
\hline \multicolumn{9}{|l|}{$\begin{array}{l}\text { Legal status (ref: fully regular: } \\
\text { RP_WP) }\end{array}$} \\
\hline Fully irregular (NRP_NWP) & $-0.22^{* * *}$ & 0.016 & $-0.25^{* * *}$ & 0.028 & $-0.21^{* * *}$ & 0.023 & $-0.20^{* * *}$ & 0.031 \\
\hline Mixed (NRP_WP) & $-0.14 * * *$ & 0.027 & $-0.20^{* * *}$ & 0.038 & 0.11 & 0.14 & $-0.11^{*}$ & 0.042 \\
\hline Mixed (RP_NWP) & $-0.077^{* * *}$ & 0.023 & $-0.13^{* * *}$ & 0.033 & -0.038 & 0.048 & 0.013 & 0.049 \\
\hline \multicolumn{9}{|l|}{ Destination (ref: France) } \\
\hline Spain & 0.0089 & 0.037 & - & - & - & - & - & - \\
\hline Italy & -0.038 & 0.034 & - & - & - & - & - & - \\
\hline Entry status: no visa (ref: visa) & -0.01 & 0.02 & 0.039 & 0.034 & $-0.060+$ & 0.035 & $-0.096^{*}$ & 0.040 \\
\hline Years in destination & $0.0099^{* * *}$ & 0.0013 & $0.010^{* * *}$ & 0.0019 & $0.014^{* * *}$ & 0.0024 & $0.010^{* * *}$ & 0.0024 \\
\hline $\begin{array}{l}\text { Period of arrival: post-1990 } \\
\text { (ref: pre-1990) }\end{array}$ & 0.032 & 0.029 & 0.017 & 0.046 & -0.030 & 0.054 & 0.011 & 0.071 \\
\hline $\begin{array}{l}\text { Age at start of current migration } \\
\text { spell }\end{array}$ & -0.00029 & 0.002 & 0.000082 & 0.0032 & -0.0011 & 0.0026 & -0.00021 & 0.0046 \\
\hline Sex: Male (ref: female) & 0.01 & 0.031 & -0.035 & 0.051 & -0.0081 & 0.046 & 0.051 & 0.063 \\
\hline Years of education & $0.0058^{*}$ & 0.0025 & $0.012^{* *}$ & 0.0042 & 0.00091 & 0.0035 & 0.0016 & 0.0060 \\
\hline Ethnicity: Wolof (ref:: other) & 0.034 & 0.029 & -0.018 & 0.052 & $0.12^{* *}$ & 0.039 & 0.043 & 0.056 \\
\hline Religion: Mouride (ref.: other) & 0.047 & 0.032 & 0.042 & 0.067 & 0.038 & 0.042 & 0.030 & 0.052 \\
\hline \multicolumn{9}{|l|}{ Economic activity (ref:: unemployed) } \\
\hline Employed & 0.036 & 0.031 & -0.065 & 0.058 & $0.18^{* * *}$ & 0.042 & 0.053 & 0.053 \\
\hline Inactive & 0.0029 & 0.035 & -0.084 & 0.062 & $0.14^{* *}$ & 0.054 & -0.069 & 0.065 \\
\hline $\begin{array}{l}\text { Occupation: self-employed } \\
\text { (ref:: other) }\end{array}$ & -0.018 & 0.024 & 0.022 & 0.076 & 0.015 & 0.037 & -0.045 & 0.036 \\
\hline $\begin{array}{l}\text { Self-reported econ. status: good } \\
\text { (ref.: bad) }\end{array}$ & 0.041 & 0.035 & -0.075 & 0.047 & -0.088 & 0.099 & $0.11^{*}$ & 0.053 \\
\hline Number of contacts at destination & 0.0011 & 0.004 & -0.0054 & 0.0060 & -0.011 & 0.0079 & 0.014 & 0.0094 \\
\hline Number of trips & 0.009 & 0.012 & 0.022 & 0.017 & -0.015 & 0.024 & -0.019 & 0.032 \\
\hline $\begin{array}{l}\text { Does not speak language of } \\
\text { destination }\end{array}$ & -0.022 & 0.029 & 0.057 & 0.12 & $-0.099^{* *}$ & 0.036 & 0.0017 & 0.051 \\
\hline Kids in Senegal (ref:: no) & -0.0018 & 0.019 & -0.038 & 0.035 & 0.045 & 0.035 & 0.014 & 0.031 \\
\hline Spouse in Senegal (ref.: no) & $0.15^{* * *}$ & 0.026 & $0.082+$ & 0.047 & $0.073+$ & 0.040 & $0.22^{* * *}$ & 0.041 \\
\hline $\begin{array}{l}\text { Geographic origin: from Dakar } \\
\text { (ref.: other) }\end{array}$ & 0.021 & 0.028 & -0.0096 & 0.049 & -0.045 & 0.038 & $0.095+$ & 0.051 \\
\hline $\begin{array}{l}\text { Father's ed.: < secondary school } \\
\text { (ref.: more) }\end{array}$ & -0.016 & 0.029 & 0.023 & 0.047 & -0.0019 & 0.043 & -0.034 & 0.056 \\
\hline Trip paid by family (ref.: no) & -0.013 & 0.027 & -0.027 & 0.045 & -0.037 & 0.044 & 0.0082 & 0.055 \\
\hline Plan to stay: definitive (ref.: no) & -0.01 & 0.025 & 0.011 & 0.046 & -0.0018 & 0.036 & -0.014 & 0.050 \\
\hline $\begin{array}{l}\text { Trip motivation: work/better } \\
\text { life (ref:: other) }\end{array}$ & -0.0044 & 0.025 & 0.018 & 0.046 & 0.0041 & 0.037 & -0.024 & 0.061 \\
\hline $\begin{array}{l}\text { At least one parent alive in Sn. } \\
\text { (ref.: no) }\end{array}$ & $-0.053^{*}$ & 0.022 & -0.014 & 0.032 & -0.058 & 0.038 & -0.054 & 0.045 \\
\hline Log likelihood & -3411.38 & & -1608.37 & & -883.35 & & -851.44 & \\
\hline$\rho$ (latent) & 0.51 & & 0.507 & & 0.317 & & 0.637 & \\
\hline Pearson's r (manifest) & 0.3 & & 0.347 & & 0.192 & & 0.431 & \\
\hline Observations (person-years) & 8119 & & 3676 & & 2089 & & 2354 & \\
\hline
\end{tabular}

Source: MAFE-Senegal. Notes: $+p<0.10,{ }^{*} p<0.05,{ }^{* *} p<0.01, * * * p<0.001$. Average marginal effects (AMEs) calculated with individual-specific intercept assumed at mean of distribution of random intercepts. Pearson's $r$ evaluated at median linear predictor 
Table 3 Multivariate results for random-intercept regression models of remittances

\begin{tabular}{|c|c|c|c|c|c|c|c|c|}
\hline \multirow[t]{2}{*}{ Predictor } & \multicolumn{2}{|l|}{ I. Pooled } & \multicolumn{2}{|l|}{ II. France } & \multicolumn{2}{|l|}{ III. Spain } & \multicolumn{2}{|l|}{ IV. Italy } \\
\hline & AME & se & AME & se & AME & se & AME & se \\
\hline Short return (ref.: none) & $0.060^{* * *}$ & 0.011 & $0.055^{* *}$ & 0.018 & 0.026 & 0.016 & $0.10^{* * *}$ & 0.026 \\
\hline \multicolumn{9}{|l|}{$\begin{array}{l}\text { Legal status (ref: fully regular: } \\
\text { RP_WP) }\end{array}$} \\
\hline Fully irregular (NRP_NWP) & $-0.11^{* * *}$ & 0.021 & 0.017 & 0.030 & $-0.11^{* *}$ & 0.035 & -0.045 & 0.027 \\
\hline Mixed (NRP_WP) & $0.056^{*}$ & 0.026 & $0.13^{* * *}$ & 0.038 & -0.026 & 0.073 & 0.039 & 0.030 \\
\hline Mixed (RP_NWP) & -0.03 & 0.02 & -0.047 & 0.034 & -0.033 & 0.031 & 0.013 & 0.033 \\
\hline \multicolumn{9}{|l|}{ Destination (ref: France) } \\
\hline Spain & 0.012 & 0.042 & - & - & - & - & - & - \\
\hline Italy & -0.036 & 0.048 & - & - & - & - & - & - \\
\hline Entry status: no visa (ref: visa) & $-0.034+$ & 0.02 & -0.000041 & 0.027 & $-0.18^{* *}$ & 0.063 & 0.010 & 0.045 \\
\hline Years in destination & $0.022^{* * *}$ & 0.002 & $0.018^{* * *}$ & 0.0027 & $0.028^{* * *}$ & 0.0055 & $0.026^{* * *}$ & 0.0043 \\
\hline $\begin{array}{l}\text { Period of arrival: post-1990 } \\
\text { (ref: pre-1990) }\end{array}$ & -0.015 & 0.038 & 0.052 & 0.054 & $-0.10+$ & 0.061 & -0.045 & 0.086 \\
\hline $\begin{array}{l}\text { Age at start of current migration } \\
\text { spell }\end{array}$ & 0.0026 & 0.0025 & -0.00035 & 0.0038 & 0.0025 & 0.0040 & 0.0045 & 0.0053 \\
\hline Sex: Male (ref: female) & -0.029 & 0.04 & -0.060 & 0.062 & 0.11 & 0.080 & 0.0083 & 0.071 \\
\hline Years of education & $-0.0066+$ & 0.0035 & $-0.013^{*}$ & 0.0056 & -0.0066 & 0.0058 & 0.0040 & 0.0067 \\
\hline Ethnicity: Wolof (ref:: other) & 0.0085 & 0.039 & -0.054 & 0.073 & 0.052 & 0.062 & -0.011 & 0.065 \\
\hline Religion: Mouride (ref:: other) & 0.0022 & 0.041 & 0.037 & 0.074 & 0.080 & 0.062 & -0.018 & 0.059 \\
\hline \multicolumn{9}{|l|}{$\begin{array}{l}\text { Economic activity (ref:: } \\
\text { unemployed) }\end{array}$} \\
\hline Employed & $0.46^{* * *}$ & 0.05 & $0.38^{* * *}$ & 0.078 & $0.29^{* * *}$ & 0.080 & $0.35^{* * *}$ & 0.064 \\
\hline Inactive & $0.098+$ & 0.053 & -0.015 & 0.078 & -0.034 & 0.095 & $0.26^{* * *}$ & 0.075 \\
\hline $\begin{array}{l}\text { Occupation: self-employed } \\
\text { (ref:: other) }\end{array}$ & $-0.048+$ & 0.027 & 0.036 & 0.064 & $-0.097^{*}$ & 0.043 & -0.012 & 0.029 \\
\hline $\begin{array}{l}\text { Self-reported econ. status: good } \\
\text { (ref.: bad) }\end{array}$ & -0.026 & 0.034 & -0.0036 & 0.060 & $-0.49^{*}$ & 0.20 & $-0.11^{* *}$ & 0.042 \\
\hline Number of contacts at destination & $-0.0074+$ & 0.0038 & $-0.014^{* *}$ & 0.0053 & 0.0045 & 0.0075 & 0.0055 & 0.010 \\
\hline Number of trips & $0.072^{* * *}$ & 0.017 & $0.12^{* * *}$ & 0.034 & -0.059 & 0.045 & $0.12^{* *}$ & 0.046 \\
\hline $\begin{array}{l}\text { Does not speak language of } \\
\text { destination }\end{array}$ & $0.081^{*}$ & 0.035 & -0.26 & 0.22 & 0.010 & 0.054 & 0.088 & 0.065 \\
\hline Kids in Senegal (ref.: no) & $0.072^{* * *}$ & 0.02 & 0.047 & 0.030 & $0.15^{* * *}$ & 0.037 & $0.083^{*}$ & 0.036 \\
\hline Spouse in Senegal (ref.: no) & $0.038+$ & 0.021 & 0.040 & 0.036 & -0.015 & 0.031 & $0.063+$ & 0.035 \\
\hline $\begin{array}{l}\text { Geographic origin: from Dakar } \\
\text { (ref.: other) }\end{array}$ & -0.037 & 0.038 & -0.034 & 0.066 & -0.053 & 0.064 & -0.041 & 0.057 \\
\hline $\begin{array}{l}\text { Father's ed.: < secondary school } \\
\text { (ref.: more) }\end{array}$ & $-0.063+$ & 0.037 & 0.026 & 0.065 & -0.058 & 0.059 & $-0.16^{* *}$ & 0.052 \\
\hline Trip paid by family (ref.: no) & -0.0051 & 0.038 & 0.092 & 0.062 & -0.12 & 0.080 & -0.052 & 0.066 \\
\hline Plan to stay: definitive (ref:: no) & $-0.099 * *$ & 0.033 & 0.060 & 0.053 & -0.061 & 0.053 & $-0.13^{*}$ & 0.057 \\
\hline $\begin{array}{l}\text { Trip motivation: work/better life } \\
\text { (ref.: other) }\end{array}$ & $0.14^{* * *}$ & 0.035 & 0.013 & 0.049 & 0.031 & 0.061 & $0.34^{* *}$ & 0.11 \\
\hline $\begin{array}{l}\text { At least one parent alive in } \mathrm{Sn} \text {. } \\
\text { (ref.: no) }\end{array}$ & $0.12^{* * *}$ & 0.024 & $0.15^{* * *}$ & 0.036 & $0.26^{* * *}$ & 0.051 & -0.054 & 0.039 \\
\hline Log likelihood & -1938.61 & & -907.774 & & -483.250 & & -425.263 & \\
\hline
\end{tabular}


Table 3 Multivariate results for random-intercept regression models of remittances (Continued)

\begin{tabular}{lllll}
\hline$\rho$ (latent) & 0.9 & 0.896 & 0.946 & 0.944 \\
Pearson's r (manifest) & 0.71 & 0.707 & 0.783 & 0.782 \\
Observations (person-years) & 8119 & 3676 & 2089 & 2354 \\
\hline
\end{tabular}

Source: MAFE-Senegal. Notes: $+p<0.10,{ }^{*} p<0.05,{ }^{* *} p<0.01, * * * p<0.001$. Average marginal effects (AMEs) calculated with individual-specific intercept assumed at mean of distribution of random intercepts. Pearson's $r$ evaluated at median linear predictor

regression of yearly reports of remitting. Compared to migrants with fully regular (RP_WP) status, those migrants with fully irregular (NRP_NWP) status are almost eleven percentage points less likely to report remitting in any given year, whatever their socio-economic status. Models II through IV show, however, that this effect is concentrated exclusively among migrants with irregular status in Spain. In addition to the negative effect of yearly irregular status, the negative effect of having entered without a visa that appears in the pooled model is also exclusively concentrated among migrants in Spain. It is worth noting, however, that the predicted probability of remitting from this country is still relatively high even for migrants with fully irregular status, indicating a near-universality of remitting among Senegalese migrants and an ability to circumvent formal barriers to these transfers.

The results thus show that the structural exclusion hypothesis is not fully supported: net of the socio-economic situation, legal status has no effect in France and Italy and a moderate effect in the Spanish context. This could be explained by the fact that migrants do not need to have the benefit of a legal status to be able to transfer money in their home country: they can use their own social network (co-ethnics bringing money home when they travel) or alternative services developed outside of the bank system, which they can access whatever their legal status (Ezeoha, 2013; Sarr, 2009). Furthermore, the insecurity associated with an irregular status may encourage some migrants to remit: in contexts where the risk of deportation is high, remitting is a way to insure that money earned abroad will remain accessible in case of forced return (Pozo, 2005). These two arguments could explain the specificity of the Spanish results: on the one hand, the higher percentage of migrants with irregular status in this country ( $21 \%$, see Table 1$)$ reduces the potential number of co-ethnics able to travel home with remittances due to territorial confinement; on the other hand, the relative tranquility of irregular migrants in Spain (Carnet, 2007; Tandian \& Bergh, 2014) compared to those subject to harsh policies in France and Italy (Finotelli \& Sciortino, 2009; Schain, 2008) - at least in some periods-may explain the finding that irregular migrants are less prone to remit in Spain than in the two other countries. In any case, the relationship between legal status and remitting is heavily dependent on the context of reception.

\section{Hypothesis 3: maintenance of social ties}

The third hypothesis is that visits to the homeland will promote other forms of nonmobile transnational engagement through the maintenance of social ties and the ability to gather first-hand information. Model I in Table 3 displays the direct effects of short visits to the homeland in the same year on remitting, net of the effects of other variables known to influence monetary transfers, such as family ties in the home country. There is indeed a positive direct relationship between visiting home and remitting. 
Overall, returning to Senegal for a visit is associated with an increase of 6 percentage points in the probability of remitting.

Other variables also indicate the importance of circulating between destination and origin for ongoing non-mobile cross-border engagement. On one hand, the number of trips (i.e. previous stays of at least one year in the same country) is highly predictive of transnational engagement: each additional prior trip is associated with a 7.2 percentage-point increase in the probability of remitting. Repeat migration (approximately $30 \%$ of the sample reported more than one trip) thus reinforces the transnational social field in such a way as to make non-mobile transnational action more likely for both individual and collective activities. On the other hand, migrants who reported planning to stay definitively in the destination country (as reported by $46 \%$ of the sample) are 10 percentage points less likely to remit than those who do not plan to stay definitively, indicating that remitting is integral to Senegalese migrants' ability to prepare an eventual return to Senegal. Migrants who reported having migrated principally for work or in search of a better life are 14 percentage points more likely to remit, suggesting that those migrants with motivations of accumulation are more likely to participate in financial cross-border action.

Overall, circulating-be it in the short or long term, retrospectively measured or planned in the future-thus seems to create an incentive to remit. This result is in line with research that finds that remitting is a financial decision that migrants make in conjunction with their families (Stark, 1991): migrants decide whether to send money to family in Senegal in response to personal and collective desires. Decisions to remit are fundamentally about allocation of resources in an extended family unit and are thus responsive to bonds of trust, emotion, and mutual obligation with the receivers of those resources (Carling, 2008; Menjivar et al., 1998). Financial decisions are thus subject to first-hand ties and the ability to gather information: as hypothesized, short visits to Senegal allow migrants to strengthen social ties and gather information about the potential uses of remittances via physical presence. Circulation over a longer term in the form of multiple trips also predicts a higher probability to remit. These effects appear very clearly in the pooled model, but they appear to be somewhat context dependent. In particular, none of the circulation variables displays significant effects on remitting among Senegalese migrants in Spain. We discuss further below the specificity of the results in the Spanish context.

\section{Hypothesis 4: caging and indirect effects of legal status via short returns}

While Table 3 displays the negative direct effects of irregular legal statuses and the positive direct effects of visits to the homeland on the remittances of Senegalese migrants, these models do not allow testing of the hypothesis of an indirect effect of irregular statuses on remitting via territorial confinement (see Fig. 1 for the theoretical model). Table 4 presents results from the non-linear decomposition of total effects using the KHB method and shows the direct, indirect, and total effects ${ }^{5}$ of irregular legal statuses on remitting.

Results from the pooled model indicate an overall significant negative effect of fully irregular status on remitting, a global effect that can be decomposed into direct and indirect effects. The direct effect corresponds to the structural exclusion hypothesis and explains $86 \%$ of the total negative effect of the fully irregular legal status (NRP_NWP). The indirect effect, via the mediator of reduced short returns, explains $14 \%$ of the total 
Table 4 KHB decomposition of effects of legal status categories on remitting via short returns

\begin{tabular}{|c|c|c|c|c|c|c|c|}
\hline & $\begin{array}{l}\text { Legal status } \\
\text { (ref: fully regular } \\
\text { or visa at entry) }\end{array}$ & $\begin{array}{l}\text { Total effect } \\
(=\text { direct }+ \\
\text { indirect })\end{array}$ & $\begin{array}{l}\text { Direct } \\
\text { effect }\end{array}$ & $\begin{array}{l}\text { Indirect } \\
\text { effect }\end{array}$ & $\begin{array}{l}\text { Confounding } \\
\text { ratio (total/ } \\
\text { direct) }\end{array}$ & $\begin{array}{l}\text { Confounding } \\
\text { percentage } \\
\text { (indirect/total) }\end{array}$ & $\begin{array}{l}\text { Indirect/ } \\
\text { direct } \\
\text { ratio }\end{array}$ \\
\hline \multirow[t]{4}{*}{ Pooled } & Fully irregular & $-2.122^{* * *}$ & $-1.828^{* * *}$ & $-0.293^{* * *}$ & 1.16 & $13.81 \%$ & 0.16 \\
\hline & Mixed (no RP) & $0.817+$ & $0.985^{* *}$ & $-0.169^{* * *}$ & 0.83 & $-20.69 \%$ & -0.17 \\
\hline & Mixed (no WP) & $-0.725^{* *}$ & $-0.584^{*}$ & $-0.141^{* *}$ & 1.24 & $19.45 \%$ & 0.24 \\
\hline & No visa at entry & -0.39 & -0.39 & -0.0043 & 1.00 & $1.10 \%$ & 0.01 \\
\hline \multirow[t]{4}{*}{ France } & Fully irregular & $-0.63+$ & -0.34 & $-0.30^{* * *}$ & 1.85 & $48 \%$ & 0.88 \\
\hline & Mixed (no RP) & $2.07^{* *}$ & $2.31^{* * *}$ & $-0.23^{* *}$ & 0.90 & $-11 \%$ & -0.10 \\
\hline & Mixed (no WP) & $-0.81^{*}$ & $-0.63+$ & $-0.19^{* *}$ & 1.29 & $23 \%$ & 0.30 \\
\hline & No visa at entry & 0.49 & 0.44 & 0.048 & 1.11 & $10 \%$ & 0.11 \\
\hline \multirow[t]{4}{*}{ Spain } & Fully irregular & $-3.46^{* * *}$ & $-3.32^{* * *}$ & -0.14 & 1.04 & $4 \%$ & 0.04 \\
\hline & Mixed (no RP) & -1.16 & -1.20 & 0.040 & 0.97 & $-3 \%$ & -0.03 \\
\hline & Mixed (no WP) & $-1.10^{*}$ & $-1.06+$ & -0.04 & 1.04 & $4 \%$ & 0.04 \\
\hline & No visa at entry & $-3.14^{* * *}$ & $-3.11^{* * *}$ & -0.02 & 1.01 & $1 \%$ & 0.01 \\
\hline \multirow[t]{4}{*}{ Italy } & Fully irregular & $-3.19^{* * *}$ & $-2.54^{* * *}$ & $-0.65^{* * *}$ & 1.26 & $20 \%$ & 0.26 \\
\hline & Mixed (no RP) & -0.08 & 0.20 & -0.28 & -0.40 & $350 \%$ & -1.40 \\
\hline & Mixed (no WP) & -0.95 & -0.77 & -0.19 & 1.23 & $20 \%$ & 0.25 \\
\hline & No visa at entry & -0.27 & -0.15 & -0.12 & 1.80 & $44 \%$ & 0.80 \\
\hline
\end{tabular}

Notes: ${ }^{* *} p<0.001,{ }^{* *} p<0.01,{ }^{*} p<0.05,+p<0.1$; logit coefficients displayed. KHB method. All models control for variables listed in Table 3

Source: MAFE-Senegal

negative effect of the same status when the three destination countries are considered together. Results vary substantially, however, across destinations. Although observed in the three contexts, the negative effect of a fully irregular status on remitting is much stronger (more significant and with a higher coefficient) in Spain and Italy than in France. Mechanisms behind this negative effect also differ by destination. In Spain, the negative association between fully irregular status and remitting is fully captured by the direct effect, or the structural exclusion hypothesis discussed above. On the contrary, in France and Italy, the negative effect of a fully irregular status is mostly indirect due to the mechanism of lesser direct contacts through reduced visits to Senegal. The lack of ability to maintain and reinforce these social ties translates into reduced remitting. Irregular status serves to confine migrants to the territory of the destination and, and thus cages their non-mobile transnational engagement in France and Italy. The KHB method thus provides evidence to support the hypothesis of an indirect effect of territorial confinement on remitting, but only in select contexts of reception.

\section{Discussion: legal status, national context and remittances}

Figure 3 provides a synthetic view of the results produced with logit models and with the KHB decomposition. It allows a clear view of how the relationships between legal status and mobile and non-mobile transnational practices vary according to the destination context.

The straightforward confirmation of the territorial confinement hypothesis is the first important result (see Fig. 3, col. A). The results unambiguously show that Senegalese migrants with a fully irregular status are significantly less likely to make short returns to the homeland. Insecure legal statuses impose a direct constraint on migrants' 


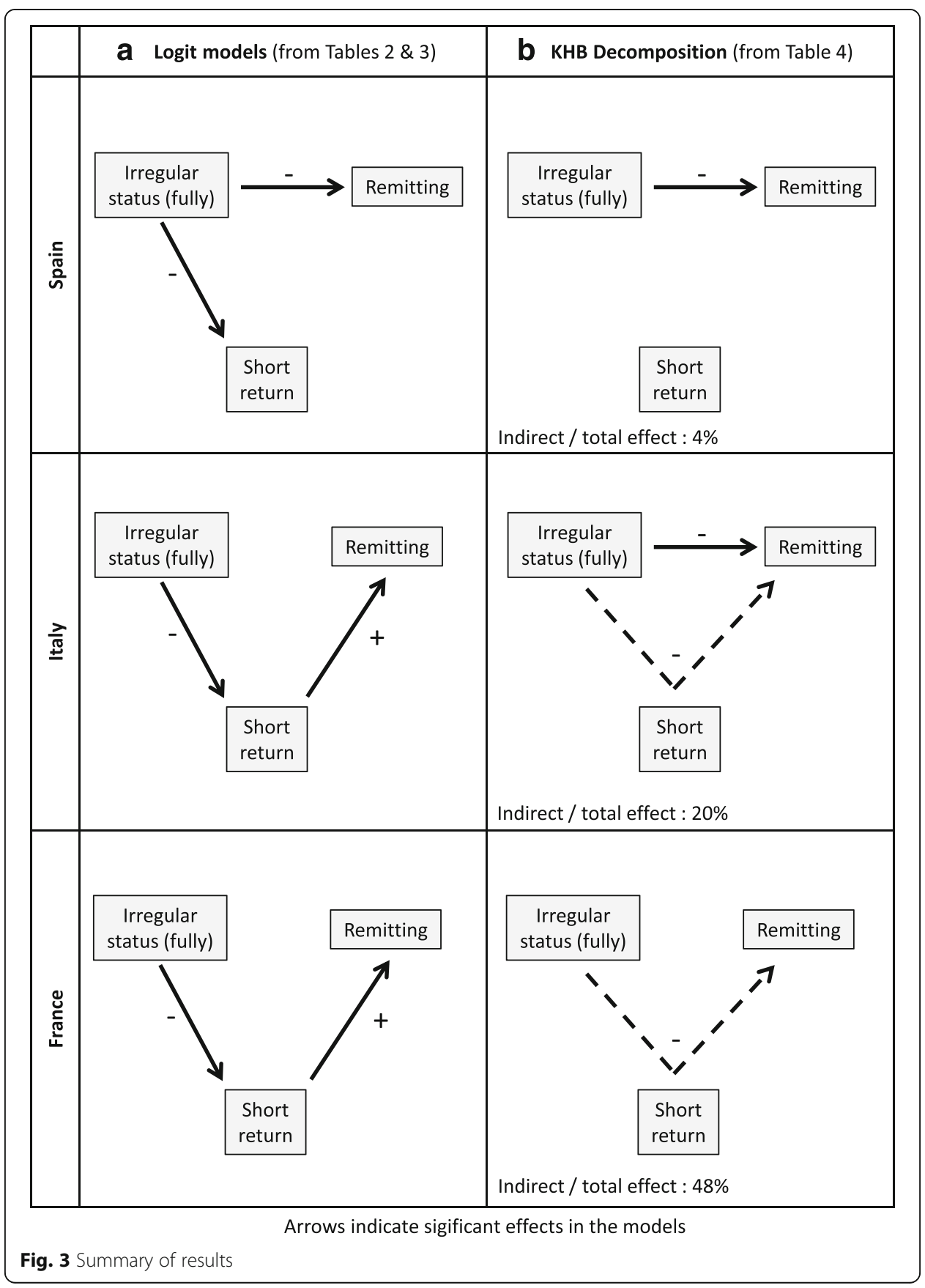

physical mobility. As expected, migrants are at the mercy of state immigration-control mechanisms for their ability to make trips back to the homeland.

As visits to the home country are considered to be instrumental for migrants to maintain social links and collect accurate information on the uses of the remittances they send, we hypothesized that an irregular legal status not only directly affects the ability to travel back and forth, but is also indirectly related to the propensity to engage in non-mobile transnational activities, such as remitting, through constraints on circulation and thus also on the co-presence important for the maintenance of social ties. The results confirm this theoretical expectation only partially. On one hand, the idea 
that visits augment the propensity to remit is not observed in all contexts: while it is confirmed in Italy and France, there is no significant relationship between short returns and remitting in Spain (Fig. 3, col. A). On the other hand, when the expected relationship between short returns and remitting is evident, the KHB decomposition confirms a significant indirect effect of a fully irregular status on the probability to remit (Fig. 3, col. B, Italy and France).

How to explain that this mechanism is not at play in the Spanish context? Why do visits to the homeland not transform into more active remitting behaviors among migrants living in this country? A possible explanation reverts to differences in the initial selection of migrants by destination: it might be that, from the onset (i.e., the decision to out-migrate), migrants heading to Spain are driven by more individualistic motivations and less prone to support family members left behind in Senegal. To put it shortly, Senegalese migrants to Spain could be "adventurers" more commonly than in Italy, and especially more than in France, where settlement patterns have long been focused on family reunification. This can be exemplified by the popularization of the motto "Barsa wala Barsakh"-a Wolof phrase meaning "Barcelona or Die"-among Senegalese youth (Mbaye, 2014). Senegalese migrants in Spain may also be less enmeshed in social structures that encourage migrants to support families and communities in Senegal. In France, where the Senegalese community has been well established since the 1970s, hometown associations exert a strong social pressure on migrants to encourage them to keep financial connections with origin families and communities (Chort, Gubert, \& Senne, 2012). In Italy, Murid organizations play an important role to remind migrants their social and economic obligations towards their home country (Kaag, 2008; Riccio, 2001). In contrast, the Senegalese community is much more recent in Spain than in France (Beauchemin, Sakho, Schoumaker, \& Flahaux, 2014) and, although there is no comparative measure of the social pressure exerted at destination by migrants organizations, it may be lesser in Spain than in the two other countries partly because of the recency of these organizations and the relative diffusion of Senegalese migrants in rural areas of Spain (Sow, 2005). The professional profiles of Senegalese migrants that stem from this selection may also play a role in limiting the relationship between returns and remitting. Senegalese in Spain are more likely to be concentrated in economic sectors that are not linked to circulation, such as agriculture and construction, while Senegalese in Italy are more likely to be independent entrepreneurs whose livelihoods depend on circulating between Italy and Senegal for commercial purposes.

The absence of relationship between mobile transnationalism (visits to Senegal) and non-mobile transnational engagement (remitting) is not the only specificity of the Spanish case. Compared to France and Italy, Spain also stands out by the fact that this is the only country where the structural exclusion hypothesis is confirmed (i.e. where irregular migrants are significantly less likely to remit than migrants with full right to stay and work), and where the negative effect of the legal status is almost totally absorbed by this direct effect (see horizontal arrows in Fig. 3, col. A and B).

How to explain that the structural exclusion/blocked transnationalism hypothesis is not confirmed in the other countries? Several mechanisms may be at play. As the migrants' economic situation is controlled for in the models, we discard here the idea that a lesser economic precarity of irregular migrants in France or Italy would explain 
that the structural exclusion effect is not observed there. Initial selection into migration to one destination or the other may again play a role: irregular migrants to Spain could be selected among the most individualistic persons, while the other destinations would be preferred by more collective-oriented migrants as a possible result of different sorts of migration networks. Another mechanism is related to the practical and institutional possibilities to remit for irregular migrants. If they cannot access banks for formal transfers, they usually rely on their co-ethnics to transfer money: relatives or friends are asked to bring money back home when they return or entire informal money-transfer services exist as complements to other commercial activities (Sarr, 2009). Such a mechanism requires that irregular migrants have people able to travel on whom they can rely, or established commercial networks linking entrepreneurs in the destination country to counterparts in Senegal. This is certainly more the case in France or Italy, where irregular migrants are proportionally less numerous and migrant organizations more established (Chort et al., 2012), and where irregular migrants have thus a more stable social and economic infrastructure to organize their informal transfers. A third mechanism could be related to the policy pressure exerted by governments on irregular migrants. Compared to migrants with irregular status in France and Spain, who face harsh deportation policies (Finotelli \& Sciortino, 2009; Schain, 2008), irregular migrants in Spain have lived under a more tolerant policy regime where regularizations are common and even migrants in irregular status have access to health services, education, and public housing (Tandian \& Bergh, 2014; Van Nieuwenhuyze, 2008). Senegalese in Spain face a lower risk of deportation than Senegalese in France and Italy, and may thus be less likely to engage in remitting as insurance policy against forced return (Pozo, 2005).

\section{Conclusion}

We have shown in this study that migrants who have irregular status may face three kinds of legal constraints on their cross-border actions: a direct legal constraint on their physical mobility, limiting short returns to the homeland; a direct legal constraint on their formal institutional participation, limiting their remitting; and an indirect legal constraint on their remitting through their inability to visit home and the concomitant curtailing of social ties. Previous studies of transnational activities, in overlooking the relationship between visits home and non-mobile transnational activities, have thus neglected an important mechanism for the constraint that legal status may have on cross-border action.

We have shown some variations across countries in patterns of direct and indirect effects, especially on remitting. France and Spain appear as opposite models as for the relationships between legal status, mobile and non-mobile transnational practices. In the former country, legal status has predominantly an indirect effect on remitting, through the mediation of visits to Senegal. These irregular migrants have a lower probability of remitting because they are trapped at destination and limited in their ability to maintain social connections at origin. On the contrary, in Spain, the effect of the legal status is predominantly direct and has almost nothing to do with the ability to move back and forth between origin and destination. Factors explaining these differences are multiple and revert to various elements of context of reception, such as: the policy treatment of irregular migrants (from tolerance to deportation), the social infrastructure at destination (with migrant organizations encouraging and facilitating money transfers), the 
initial selection of migrants towards one destination or another. Future research would need to examine more carefully these potential factors of national differences. In any case, whatever the destination context, the lack of a secure status creates a situation of territorial confinement.

This study takes up Levitt's (Levitt, 2015, p. 2284) challenge to examine the "how, why, and where" of the persistence or dissipation of transnational activities. In finding nuanced relationships between the legal status of Senegalese migrants and a subset of their transnational activities, we have sought to demonstrate that different types of cross-border engagement are sensitive not only to the characteristics of the migrants and their homeland communities, but also to the legal constraints that they face in their contexts of reception. By considering Senegalese migrants in three distinct contexts of reception, this study heeds the call (Levitt, 2015) to extend the concepts of territorial confinement and caging (Waldinger, 2008, 2015) beyond the Mexico-US migration system. We have used an empirical case that offers the advantage of harmonized data across multiple destination countries, which has allowed us to extend Waldinger's $(2008,2015)$ territorial-confinement hypothesis by demonstrating that not all transnational activities in all destinations are equally sensitive to the legal constraint of irregular status. While there is an unambiguous negative effect of irregular status on visits home, both the direct and indirect effects of irregular status on remittances depend on other social and economic facets of the co-ethnic community and the context of reception.

While this study contributes to the literature on transnational activities, its findings are subject to limitations. The largest of these are related to the data: while innovative and rich, the MAFE data are limited by sampling strategy, sample size, and measurement strategies. In most of the European countries (with the exception of Spain), no sampling frame was available. The samples constructed on the basis of quota methods may not be representative of Senegalese migrants in each country (e.g., they might over-represent migrants well-connected to the co-ethnic community). Furthermore, the national samples were relatively small, thus any empirical results could suffer from lack of precision. The survey's measurement strategy ensured comparable variables across national contexts, which allowed comparative analysis, and over time, but the retrospective data are potentially limited by recall bias and many variables remained unmeasured. Variables important for this study that were not measured include mode and frequency of communication with family and friends in Senegal, method of remittance sending, and measures of strength of social ties with family. Future research should seek to address these gaps.

Our findings have implication for policies of immigration control, immigrant integration, and co-development. Modern nation-states place contradictory demands on migrant's cross-border activities. On the one hand, many destination-country governments have started to recognize the role that migrants can and do play in the development of their homelands and have put in place "co-development" schemes (Kabbanji, 2013; Weil, 2002) to leverage transnational activities for the benefit of development programs. On the other hand, states have erected increasingly restrictive immigrationcontrol apparatuses that make it difficult to acquire secure legal status. This difficulty translates into a captured loyalty among legal migrants, who have invested heavily in their membership, and a physical territorial confinement of those migrants who lack 
regular status. The immigration-control control apparatus, coupled with a dominant ideology of assimilation that often looks askance at foreign loyalties, thus implicitly limits the cross-border activities of both documented and undocumented migrants.

At the same time, the robustness of the social infrastructure of most transnational activities indicates that irregularity of legal status may constrain but does not completely determine cross-border action. While the state and formal institutions may demand "papers" for the crossing of some kinds of borders, migrants clearly find ways to circumvent these demands; this study showed that even migrants completely bereft of residence and work authorization have a non-zero probability of crossing the destination state's geographical border for a short visit to Senegal. At the same time, we have shown the importance of taking legal status into account as transnational activities are subject to a number of legal constraints, both direct and indirect.

This study does lend credence, however, to the idea that the homeland and its values remain important arbiters social status for Senegalese migrants (Kaag, 2008; Kane, 2011; Riccio, 2008). There are strong effects of short visits, social ties, repeat migration, plans to return, and work-related motivation on non-mobile transnational activities. This shows that Senegalese migrants' cross-border engagement is largely motivated by a desire to return to Senegal eventually. A logic of accumulation at origin may thus dominate a logic of integration at destination (Van Nieuwenhuyze, 2008); both of these logics, however, are potentially blocked by lack of secure legal status: migrants without "papers" are both directly blocked from transnational participation via legal exclusion from border crossing, and indirectly blocked by physical caging in the destination and the concomitant withering of social ties. Legal status is thus of key importance in keeping open the door to returns to the homeland.

\section{Endnotes}

${ }^{1}$ See http://mafeproject.site.ined.fr/ for more information on the MAFE project.

${ }^{2}$ https://www.service-public.fr/particuliers/vosdroits/F2741

${ }^{3}$ This metric is "reset" for each subsequent stay in a different destination; the models include a quadratic term on years in destination to account for potential non-linearities in its effect

${ }^{4}$ All time-varying predictors are observed at time $t$. All models were also estimated with lagged predictors measured at time $t-1$ but results (not reported, available upon request) were substantively similar.

${ }^{5}$ The effects are presented as logit coefficients (log-odds) so are not directly comparable to the quantities in the random-intercept models.

Competing interests

The authors declare that they have no competing interests.

Authors' contributions

EV conducted literature searches, analyzed the data, and drafted and revised the manuscript. CB led the data-collection project, participated in defining theoretical framing, and wrote sections of the manuscript. Both authors read and approved the final manuscript.

\section{Acknowledgements}

The authors wish to acknowledge the support of Princeton University and INED. The MAFE project is coordinated by INED (C. Beauchemin) in partnership with the Université catholique de Louvain (B. Schoumaker), Maastricht University (V. Mazzucato), the Université Cheikh Anta Diop (P. Sakho), the Université de Kinshasa (J. Mangalu), the University of Ghana (P. Quartey), the Universitat Pompeu Fabra (P. Baizan), the Consejo Superior de Investigaciones Científicas

(A. González-Ferrer), the Forum Internazionale ed Europeo di Ricerche sull'Immigrazione (E. Castagnone), and the 
University of Sussex (R. Black). The MAFE project has received funding from the European Community's Seventh Framework Programme under grant agreement 217206. The MAFE-Senegal survey was conducted with the financial support of INED, the Agence Nationale de la Recherche (France), the Région lle de France and the FSP programme'International Migrations, territorial reorganizations and development of the countries of the South'.

\section{Author details}

${ }^{1}$ IZA - Institute for the Study of Labor, Washington, USA. ${ }^{2}$ French Institute for Demographic Studies (INED), Paris, France.

Received: 16 September 2015 Accepted: 14 June 2016

Published online: 03 November 2016

\section{References}

Baldassar, L. (2008). Missing Kin and Longing to be Together: Emotions and the Construction of Co-presence in Transnational Relationships. Transnational Families and Emotions. Spec. issue of Journal of Intercultural Studies, 29(3), 247-266.

Beauchemin, C. (2015). Migration between Africa and Europe (MAFE): Advantages and Limitations of a Multi-Site Survey Design. Population, English Edition, 70(1), 13-36.

Beauchemin, C., Nappa, J., Schoumaker, B., Baizan, P., González-Ferrer, A., Caarls, K., \& Mazzucato, V. (2015). Reunifying Versus Living Apart Together Across Borders: A Comparative Analysis of sub-Saharan Migration to Europe. International Migration Review, 49(1), 173-199. http://doi.org/10.1111/imre.12155.

Beauchemin, C., Sakho, P., Schoumaker, B., \& Flahaux, M.-L. (2014). New patterns of migration between Senegal and Europe MAFE Working Paper, (21), 33.

Bloch, A. (2008). Zimbabweans in Britain: Transnational Activities and Capabilities. Journal of Ethnic \& Migration Studies, 34(2), 287-305. http://doi.org/10.1080/13691830701823822.

Boccagni, P. (2012a). Rethinking transnational studies: Transnational ties and the transnationalism of everyday life. European Journal of Social Theory, 15(1), 117-132. http://doi.org/10.1177/1368431011423600.

Boccagni, P. (2012b). Revisiting the "Transnational" in Migration Studies: A Sociological Understanding. Revue Européenne Des Migrations Internationales, 28(1), 33-50.

Cameron, A. C., \& Trivedi, P. K. (2010). Microeconometrics Using Stata, Revised Edition. College Station, TX: StataCorp LP.

Carling, J. (2008). The human dynamics of migrant transnationalism. Ethnic and Racial Studies, 31(8), 1452-1477. http://doi.org/10.1080/01419870701719097.

Carnet, P. (2007). Borders: a resource for underground Economies. Borders of the European Union: Strategies of Crossing and Resistance. Retrieved from https://halshs.archives-ouvertes.fr/halshs-01170473/

Chort, I., Gubert, F., \& Senne, J.-N. (2012). Migrant networks as a basis for social control: Remittance incentives among Senegalese in France and Italy. Regional Science and Urban Economics, 42(5), 858-874.

Cisse, F. (2011). Senegal. In S. Mohapatra \& D. Ratha (Eds.), Remittance Markets in Africa. Washington, D.C.: World Bank Publications.

Diminescu, D. (2008). The connected migrant: an epistemological manifesto. Social Science Information, 47(4), 565-579. http://doi.org/10.1177/0539018408096447.

Diop, M. (1993). L'immigration ouest-africaine en Europe [West African Immigration in Europe]. Études Internationales, 24(1), 111-124.

Dunn, K. (2010). Embodied transnationalism: bodies in transnational spaces. Population, Space and Place, 16(1), 1-9. http://doi.org/10.1002/psp.593.

Ezeoha, A. E. (2013). Financial Determinants of International Remittance Flows to the Sub-Saharan African Region. International Migration, 51, e84-e97. http://doi.org/10.1111/imig.12061.

Finotelli, C., \& Sciortino, G. (2009). The Importance of Being Southern: The Making of Policies of Immigration Control in Italy. European Journal of Migration and Law, 11, 119.

Foner, N. (1997). What's New About Transnationalism?: New York Immigrants Today and at the Turn of the Century. Diaspora: A Journal of Transnational Studies, 6(3), 355-375. http://doi.org/10.1353/dsp.1997.0013.

Glick Schiller, N., Basch, L., \& Blanc, C. S. (1995). From Immigrant to Transmigrant: Theorizing Transnational Migration. Anthropological Quarterly, 68(1), 48-63. http://doi.org/10.2307/3317464.

González-Ferrer, A. (2011). The reunification of the spouse among recent immigrants in Spain. Links with undocumented migration and the labour market. In A. Kraler, E. Kofman, M. Kohli, \& C. Schmoll (Eds.), Gender, Generations and the Family in International Migration (pp. 143-166). Amsterdam: Amsterdam University Press.

Guarnizo, L. E. (2003). The Economics of Transnational Living. International Migration Review, 37(3), 666-699.

Guarnizo, L. E., Portes, A., \& Haller, W. (2003). Assimilation and Transnationalism: Determinants of Transnational Political Action among Contemporary Migrants. American Journal of Sociology, 108(6), 1211-1248. http://doi.org/10.1086/375195.

Itzigsohn, J. (2015). The Strengths and Limits of Waldinger's The Cross Border Connection. Ethnic and Racial Studies, 38(13), 2299-2304. http://doi.org/10.1080/01419870.2015.1058507.

Itzigsohn, J., \& Saucedo, S. G. (2002). Immigrant Incorporation and Sociocultural Transnationalism. International Migration Review, 36(3), 766-798.

Kaag, M. (2008). Mouride Transnational Livelihoods at the Margins of a European Society: The Case of Residence Prealpino, Brescia, Italy. Journal of Ethnic \& Migration Studies, 34(2), 271-285. http://doi.org/10.1080/ 13691830701823848.

Kabbanji, L. (2013). Towards a Global Agenda on Migration and Development? Evidence from Senegal. Population, Space and Place, 19(4), 415-429. http://doi.org/10.1002/psp.1782.

Kane, O. (2011). The Homeland is the Arena: Religion, Transnationalism, and the Integration of Senegalese Immigrants in America. Oxford: Oxford University Press.

Karlson, K. B., \& Holm, A. (2011). Decomposing primary and secondary effects: A new decomposition method. Research in Social Stratification and Mobility, 29(2), 221-237. http://doi.org/10.1016/j.rssm.2010.12.005. 
Kohler, U., Karlson, K. B., \& Holm, A. (2011). Comparing coefficients of nested nonlinear probability models. Stata Journal, 11(3), 420-438.

Levitt, P. (2015). Welcome to the Club?: A response to The Cross -Border Connection by Roger Waldinger. Ethnic and Racial Studies, 38(13), 2283-2290. http://doi.org/10.1080/01419870.2015.1058504.

Levitt, P., \& Jaworsky, B. N. (2007). Transnational Migration Studies: Past Developments and Future Trends. Annual Review of Sociology, 33(1), 129-156. http://doi.org/10.1146/annurev.soc.33.040406.131816.

Massey, D. S. (2007). Categorically Unequal: The American Stratification System. Russell Sage Foundation.

Massey, D. S., Durand, J., \& Malone, N. J. (2002). Beyond Smoke and Mirrors: Mexican Immigration in an Era of Economic Integration. New York: Russell Sage.

Mazzucato, V. (2008). The Double Engagement: Transnationalism and Integration. Ghanaian Migrants' Lives Between Ghana and The Netherlands. Journal of Ethnic and Migration Studies, 34(2), 199. http://doi.org/10.1080/ 13691830701823871.

Mazzucato, V., Schans, D., Caarls, K., \& Beauchemin, C. (2015). Transnational Families Between Africa and Europe. International Migration Review, 49(1), 142-172. http://doi.org/10.1111/imre.12153.

Mbaye, L. M. (2014). "Barcelona or die": understanding illegal migration from Senegal. IZA Journal of Migration, 3(1), 1-19. http://doi.org/10.1186/s40176-014-0021-8.

Menjivar, C., DaVanzo, J., Greenwell, L., \& Valdez, R. B. (1998). Remittance Behavior among Salvadoran and Filipino Immigrants in Los Angeles. The International Migration Review, 32(1), 97-126. http://doi.org/10.2307/2547562.

Mood, C. (2010). Logistic Regression: Why We Cannot Do What We Think We Can Do, and What We Can Do About It. European Sociological Review, 26(1), 67-82. http://doi.org/10.1093/esr/jcp006.

Mountz, A., Wright, R., Miyares, I., \& Bailey, A. J. (2002). Lives in limbo: Temporary Protected Status and immigrant identities. Global Networks, 2(4), 335-356. http://doi.org/10.1111/1471-0374.00044.

Portes, A., Guarnizo, L. E., \& Haller, W. J. (2002). Transnational Entrepreneurs: An Alternative Form of Immigrant Economic Adaptation. American Sociological Review, 67(2), 278-298.

Portes, A., Guarnizo, L. E., \& Landolt, P. (1999). The study of transnationalism: pitfalls and promise of an emergent research field. Ethnic and Racial Studies, 22(2), 217. http://doi.org/10.1080/014198799329468.

Portes, A., \& Rumbaut, R. (2006). Immigrant America: A Portrait (3rd ed.). Berkeley: University of California Press. expanded, and update.

Portes, A., \& Zhou, M. (2012). Transnationalism and Development: Mexican and Chinese Immigrant Organizations in the United States. Population and Development Review, 38(2), 191-220. http://doi.org/10.1111/j.1728-4457.2012.00489.x.

Pozo, S. (2005). On Remittances and Risk. In D. F. Terry \& S. R. Wilson (Eds.), Beyond Small Change: Making Migrant Remittances Count (pp. 71-92). Washington, D.C: Inter-American Development Bank.

Rabe-Hesketh, S., \& Skrondal, A. (2008). Multilevel and Longitudinal Modeling Using Stata (2nd ed.). College Station, Tex: Stata Press.

Riccio, B. (2001). From "ethnic group" to "transnational community"? Senegalese migrants' ambivalent experiences and multiple trajectories. Journal of Ethnic and Migration Studies, 27, 583-599.

Riccio, B. (2008). West African Transnationalisms Compared: Ghanaians and Senegalese in Italy. Journal of Ethnic \& Migration Studies, 34(2), 217-234. http://doi.org/10.1080/13691830701823913.

Sarr, P. A. (2009). Transferts de fonds des migrants et développement en Afrique : une étude de cas sur le Sénégal. Techniques Financières et Développement, 95, 15-27.

Schain, M. A. (2008). The Politics of Immigration in France, Britain, and the United States: A Comparative Study. Palgrave Macmillan.

Schiller, N. G. (2015). Explanatory frameworks in transnational migration studies: the missing multi-scalar global perspective. Ethnic and Racial Studies, 38(13), 2275-2282. http://doi.org/10.1080/01419870.2015.1058503.

Schoumaker, B., Flahaux, M.-L., Schans, D., Beauchemin, C., Mazzucato, V., \& Sakho, P. (2013). Changing Patterns of African Migration: A Comparative Analysis. (MAFE Working Paper 18 No. 18). Paris: INED. Retrieved from http://www.ined.fr/ fichier/s rubrique/22089/wp18_patternssynthesis.fr.pdf

Sow, P. (2005). Migrations sénégalaises en catalogne: diagnostic, formes de relations/communications et solidaires avec les lieux d'origine [Senegalese Migrations in Catalonia: Diagnotics, Forms of Relationships/Communications, and Solidarities with Places of Origin]. (Programme MIDEL (Migrations et Développement Local). Projet pour le dynamisation d'un espace d'échange, de cooperation et de concertation entre les migrants sénégalais et leurs communautés d'origine) (p. 106). Barcelona: Fons Català de Cooperació al Desenvolupament.

Spire, A. (2005). Etrangers à la carte: L'administration de l'immigration en France (1945-1975) [The Administration of Immigration in France (1945-1975)]. Paris: Grasset.

Stark, O. (1991). The Migration of Labor. Cambridge, Mass: B. Blackwell.

Tandian, A., \& Bergh, S. I. (2014). From Temporary Work in Agriculture to Irregular Status in Domestic Service: The Transition and Experiences of Senegalese Migrant Women in Spain. In T.-D. Truong, D. Gasper, J. Handmaker, \& S. I. Bergh (Eds.), Migration, Gender and Social Justice (Vol. 9, pp. 47-67). Berlin, Heidelberg: Springer, Berlin Heidelberg. Retrieved from http://link.springer.com/10.1007/978-3-642-28012-2_3.

Timera, M. (1997). L'immigration africaine en France: regards des autres et repli sur soi: La France et les migrants africains [The African immigration in France: the withdrawal of the other: France and the African migrants]. Politique Africaine, 67, 41-47.

Triandafyllidou, A. (Ed.). (2010). Irregular Migration in Europe: Myths and Realities. Surrey: Ashgate Publishing, Ltd.

UNODC. (2013). Transnational Organized Crime in West Africa: A Threat Assessment (p. 62). Vienna: United Nations Office on Drugs and Crime (UNODC). Retrieved from http://www.unodc.org/toc/en/reports/TOCTAWestAfrica.html

Urry, J. (2002). Mobility and Proximity. Sociology, 36(2), 255-274. http://doi.org/10.1177/0038038502036002002.

Van Meeteren, M. (2012). Transnational activities and aspirations of irregular migrants in Belgium and the Netherlands. Global Networks, 12(3), 314-332. http://doi.org/10.1111/j.1471-0374.2012.00354.x.

Van Nieuwenhuyze, I. (2008). Getting by in Europe's urban labour markets: Senegambian migrants'strategies for survival, documentation and mobility. Amsterdam: University Press.

Vertovec, S. (2003). Migration and Other Modes of Transnationalism: Towards Conceptual Cross-Fertilization. International Migration Review, 37(3), 641-665. 
Vickstrom, E. (2014). Pathways into Irregular Status Among Senegalese Migrants in Europe. International Migration Review, 48(4), 1062-1099. http://doi.org/10.1111/imre.12154.

Waldinger, R. (2015). The Cross-Border Connection: Immigrants, Emigrants, and Their Homelands. Harvard: Harvard University Press.

Waldinger, R. (2010). Rethinking transnationalism. Empiria. Revista de Metodología de Ciencias Sociales, 19, 21-38. Waldinger, R. (2008). Between "Here" and "There": Immigrant Cross-Border Activities and Loyalties. International Migration Review, 42(1), 3-29. http://doi.org/10.1111/j.1747-7379.2007.00112.x.

Weil, P. (2002). Towards a Coherent Policy of Co-Development. International Migration, 40(3), 41-55.

Wilding, R. (2006). "Virtual" intimacies? Families communicating across transnational contexts. Global Networks, 6(2), 125-142. http://doi.org/10.1111/j.1471-0374.2006.00137.

Submit your manuscript to a SpringerOpen ${ }^{\circ}$ journal and benefit from:

- Convenient online submission

- Rigorous peer review

- Immediate publication on acceptance

- Open access: articles freely available online

- High visibility within the field

- Retaining the copyright to your article

Submit your next manuscript at $>$ springeropen.com 